\title{
Finite-element analysis and simulation of machining: a bibliography (1976-1996)
}

\author{
Jaroslav Mackerle* \\ Linköping Institute of Technology, Department of Mechanical Engineering, S-581 83 Linköping, Sweden
}

Received 26 June 1997

\begin{abstract}
This paper gives a bibliographical review of the finite-element methods (FEMs) applied to the analysis and simulation of machining. The bibliography at the end of the paper contains references to papers, conference proceedings and theses/dissertations on the subject that were published in 1976-1996. The following topics are included: material removal and cutting processes in general, computational models for specific machining processes, effects of geometric and process parameters, thermal aspects in machining, residual stresses in machining, dynamic analysis and control of machine tools, tool wear and failure, chip formation mechanism, and optimization and other topics, respectively. C 1999 Elsevier Science S.A. All rights reserved.
\end{abstract}

Keywords: Finite-element method; Machining; Bibliography

\section{Introduction}

Machining is a term covering a large collection of manufacturing processes designed to remove material from a workpiece. The primary machining processes are: turning, shaping, milling, drilling, sawing, abrasive machining, and broaching. Some advanced machining methods used today are: electric discharge machining (EDMs), laser cutting, chemical milling, high-pressure water cutting, electrochemical machining, etc.

Turning is the machining process used to generate external, cylindrical forms by removing material by a cutting tool. Boring is internal turning to generate internal shapes. Shaping processes remove material from surfaces through the use of a single-point tool supported by a ram that reciprocates the tool in a linear motion against the workpiece. Milling is a process for generating surfaces by removing a predetermined amount of material from the workpiece. It employs motion between the workpiece and the rotating cutting tool. Drilling is an operation for producing round holes in materials. Sawing is a process of cutting a workpiece with power saws of various geometry. The grinding process is an abrasive machining process where material

* Tel.: + 4613281111 ; fax: + 4613282717 . is removed from a workpiece in small chips/particles by the mechanical action of abrasive particles. Finally, broaching is a process where a cutting tool that has multiple transverse cutting edges is pushed/pulled through a hole or over a surface to remove material by axial cutting. The terminology and detailed explanation of machining and metalworking operations can be found in $[1,2]$.

The direct experimental approach to study machining processes is expensive and time consuming, especially when a wide range of parameters is included: tool geometry, materials, cutting conditions, etc. The alternative approaches are mathematical simulations where numerical methods are applied. Amongst the numerical procedures, the finite-element methods (FEMs) are the most frequently used. To study machining is a quite complicated task where complex disciplines such as metallurgy, elasticity, plasticity, heat transfer, contact problems, fracture mechanics, and lubrication are involved. The goal of finite-element analysis is to derive a computational model predicting the deformations, stresses and strains in the workpiece, as well as the loads on the tool working under specific cutting parameters.

Several finite-element techniques are available today for accurate and efficient modelling of the machining 
process: material and geometrical non-linear analysis, mesh rezoning techniques, element-separation for chip formation modelling, element separation criteria, toolwear modelling, residual stress prediction, etc. In many cases the FEM simulations have also been validated by comparisons with the results of experimental investigations.

This paper gives a review of published papers dealing with FEMs applied in the area of machining processes. The subject is too large to be covered extensively in a single paper, therefore only a synoptic view will be given. For a more efficient information retrieval, the lists of references of papers published between 1976 and 1996 are divided into the following topics: (i) material removal and cutting processes in general; (ii) computational models for specific machining processes; (iii) the effects of geometric and process parameters; (iv) thermal aspects in machining; (v) residual stresses in machining; (vi) dynamic analysis and control of machine tools; (vii) tool wear and failure; (viii) the chip formation mechanism; and (iv) optimization and other topics.

This paper is organised into two parts. In the first part each topic is handled and current trends in the application of finite-element techniques are mentioned. In the second part, an appendix, papers published in the open literature for the period 1976-1996 on the subjects presented above are listed. References have been retrieved from the author's database, MAKEBASE $[3,4]$. Readers interested in finite-element literature in general are referred to [5] or to the author's Internet Finite Element Book Bibliography (http:// ohio.ikp.liu.se/fe/index.html).

\section{Material removal and cutting processes in general}

This section deals with the investigation of metal cutting processes in general. These processes are dependent on the workpiece parameters (material type, crystallography, temperature, pre-deformation), cutting tool parameters (tool design geometry, material), and cutting parameters (speed, feed, depth of cut, environment). Some studies have been done that include the influence of only a few specific topics, other, more advanced studies, have been conducted to understand the complex physical behavior underlying the specific machining process.

Two basic models are in focus: orthogonal (twoforce) models, and oblique (three-force) models. Most machining processes are oblique but the orthogonal model studies are easier to simulate and they can be useful/adequate for understanding the basic mechanics of machining processes.

The topics included in this section on numerical simulations of material removal are: the material-removal process; surface development; orthogonal cut- ting; oblique cutting; sheet cutting; intermittent/interrupted cutting; conception of machine tools; cutting tool performance; metal flow studies; shear-band phenomena; strain localization; workability issues; contact stresses and friction in machining; toolwork interactions; the workpiece in a machining fixture; high-speed machining; machining additives.

The types of analysis are: 2-D and 3-D; material and geometrical non-linearity; thermomechanical; thermoelastic-plastic; thermo-viscoplastic; elasto-plastic; viscoplastic; rigid-plastic; large deformation; ALE thermomechanical; Eulerian; adaptive remeshing.

The types of material are: metal; steel; aluminium; titanium alloy; nickel-base superalloy; ceramic; composite; polymer; ceramic tools; carbide tools; tungsten carbide tools; diamond tools.

\section{Computational models for specific machining processes}

Listed references are sorted into the following categories: turning, milling, drilling, sawing, grinding, broaching, and advanced machining; in the last category subjects such as EDM, laser cutting, electrochemical machining, flame cutting, high-pressure water cutting, ultrasonic machining, nanoscale cutting etc. are included.

The machining of composites, especially of metal matrix composites, causes particular problems such as greater tool wear; also the hardness of the ceramic fibres and particles is too high. Usually polycrystalline diamond-tipped tools are necessary for the successful machining of metal-matrix composite.

Physical understanding of microcutting is necessary for developing and improving the process of ultraprecision metal cutting technology. FEMs have also been used to simulate nanoscale cutting. The purpose of these studies was to clarify the chip removal of nanoscale cutting and to reexamine the cutting process in general.

The topics included in this section are: turningturning and tool fracture; tool wear in turning; dynamic response in turning; machining accuracy in turning; thermal behavior of a tool during turning; cutting and clamping forces in turning; design of legs for a lathe; single point diamond turning; interrupted turning and tool chipping; finish turning; milling - modal analysis of a milling machine; dynamic response in milling; tool and tool beds design; machine-tool modelling; wear of tools in milling; analysis of cutting forces; thermal problems in milling; design of a mill spindle; face milling; plain milling cutter; helical milling cutter; end milling; hot strip milling; milling of thin-walled sections; drilling - dynamic response in drilling; thermal 
problems in drilling; design of drills; drill wear; torsional strength for twist drill; drills under bending; residual stresses in drilling; hole-drilling method of residual stress measurements; composites during drilling; burr formation in drilling; twist drills; multifacet drills; thick web drills; radial drilling machines; high speed precision drilling; sawing - modal analysis of a band system; dynamic response in sawing; sawtooth interface simulations; sawing of composites; band saw blades; circular saw rolls; grinding - thermal problems in grinding; machine-tool interaction; grinding and phase transformation; residual stresses in grinding; design of grinding wheels; fracture of grinding wheels; bonded grinding wheels; abrasive and superabrasive grinding wheels; grinding burrs; creep-feed grinding; high-speed grinding; ultrahigh-speed grinding; cylindrical transverse grinding; plunge grinding; surface grinding; wet grinding; crankpin grinder; microgrinding; broaching-tool-workpiece in broaching; forces, power, stress and displacement in broaching; advanced machining-laser machining; ultrasonic machining; electrochemical machining; surface micromachining; nanoscale cutting; superprecision machining; EDM; plasma and flame cutting; high-pressure water jet cutting; applications in-electronics, acoustics, precision engineering, machining of composites, machining of ceramics.

\section{Effects of geometric and process parameters}

For every machining operation it is necessary to select a cutting speed, a feed, and depth of cut. New cutting tool materials and tool geometries are improving product quality and manufacturing productivity. Papers presented in this section try to study the connections between these input variables and process behavior. A large number of the input variables makes it almost impossible to deal with a such complex situation. Available mathematical models try to predict the direction of the shearing process of metal cutting, cutting forces, tool wear, etc. The main objective of research is to apply the FEM to study the effects of geometric and process parameters in the process of machining.

Some of the topics included are: tool geometry effects on the cutting of hardened/quenched steels; the effects of tool geometry on chip flow and wear; tool life owing to engagement angle; rake-angle effects on orthogonal cutting; the effects of tool geometry on punching; the effects of tool geometry on dynamic vibrations; the modelling of machining under various cutting conditions; metal cutting parameters and manufacturing accuracy.

\section{Thermal aspects in machining}

High temperatures in machining are the cause of unsatisfactory tool life and limitations on cutting speed. Various numerical and experimental techniques are available to study the flow of cutting heat and the temperature distribution within both the workpiece and the tool. The role of temperature becomes more important with increasing cutting speed and the usage of more advanced ceramic materials. The thermal model of a machine tool should account for the following heat-transfer situations: heat conduction, heat conduction across contact zones, radiation, forced convection along rotated element surfaces, free convection along external surfaces, and convection along the body surfaces that is caused by rotating parts. The finite-element model should preferably be in $3 \mathrm{D}$.

A note on the grinding process: grinding requires an extremely high energy input per unit volume of material removal compared with other machining processes. Almost all of the energy is converted to heat in the grinding zone. An elevated temperature occurs in the grinding wheel as well as in the workpiece.

The topics included in this section: temperature distribution in machining; the effect of contact pressure on heat transfer in machining; the influence of process variables on the temperature distribution; heat flow through a cutting tool; tool-work interface temperature; thermal cracking of cutting tools; control of thermal deformations; cooling in machining; effect of thermal load on the residual stress; thermal phenomena in-orthogonal machining, orthogonal micromachining, high-speed machining, milling, drilling, boring, grinding, interrupted turning, grinding, honing, laser cutting; cutting temperature in ceramic tools; thermal phenomena in bonded carbide tipped tools.

Type of analysis: 2D and 3D analysis; thermomechanical coupling; thermoelastoplastic large deformation analysis; thermoviscoplastic analysis; ALE thermomechanical analysis; rigid-plastic FEM; simulation of moving heat sources; adaptive remeshing techniques; thermal error modelling; improved thermal simulation by help of experimental data.

\section{Residual stresses in machining}

The machining process evokes a residual stress in the surface layer. The main cause of a residual stress is the phase transformation of the surface material. Distortions and residual stresses are unwanted results from abusive machining conditions. The residual stresses on the machining surface is an important factor in determining the performance and fatigue strength of components. 
Some of the topics included are: analysis and measurement of residual stresses in machining; plasticity effects on residual stress measurement; effect of thermal and mechanical loads on residual stresses; residual stresses due to a moving heat source; the effect of cutting on the redistribution of residual stresses; the effect of tool condition on residual stresses; holedrilling technique for measuring residual stresses; residual stresses in orthogonal metal cutting; residual stresses in metal grinding; residual stresses in the grinding of metal-matrix composites.

\section{Dynamic analysis and control of machine tools}

The whole cutting system includes a spindle, bearings and a cutter. The design of the spindle system dynamic characteristics is based on the variation of parameters such as the bearing preload, the bearing spacing, mass inserts on the spindle and damping. The dynamic characteristics of the spindle assembly affects the cutting ability of the whole machine.

In turning, which is a widely used machining process, self-excited or chatter vibration is a serious problem that effects the deterioration of the surface finish, affects the dimensional accuracy of the workpiece, and reduces the tool/machine lifetime. Also, forced vibrations can be induced in machine tools by component defects, unbalanced parts, poor assembly, etc. To study dynamics in turning and to reduce/suppress chatter vibration is a very important task. Fundamental studies of this complex process are still needed.

Vibration from a milling cutter occurs during machining due to slenderness and long overhang, and generates waviness on the machined surface and hence deterioration in machining accuracy/quality. There are two different approaches to study the dynamic response during machining: one is a cutting force model that does not contain many cutting parameters; the second approach is a structural dynamic model of the whole cutting system.

The topics included in this section are: cutting process dynamics; studies of dynamics phenomena in milling, grinding, turning, drilling; machine tool bed dynamics; parameter identification of machine tools; damping treatment; vibrations of machine tools; dynamic analysis of lathe spindle assembly; dynamic analysis of a high-speed spindle-bearing assembly; dynamic analysis of high-speed drilling; the dynamics of a machining robot; dynamic analysis of a saw blade; the suppression of a chatter vibration; boring bar chatter control; vibration control of cutting processes; vibration control of boring; vibration control of ultrasonic tooling.

\section{Tool wear and failure}

The failure of mechanical components is caused primarily by fatigue. In machining, mechanical and thermal loads, and phase transformation, are main factors that affect the surface integrity of a machined part. Plastic deformation and friction in the contact between the tool and the workpiece generate heat, which raises the temperature of both components. The elevated temperature of the tool reduces its wear resistance and changes both the geometry and the size. This can result in increased cutting forces with larger deflections in the workpiece and may create a chatter condition.

Cutting tools are changing constantly with new types of materials, special tool coatings and new types of cutters, mills, drills, etc. High-speed steel, cast non-ferrous alloys and cemented carbides are the most frequently used turning, milling and boring tool materials. Other advanced materials include: coated/uncoated tungsten carbides, cermets, ceramics and polycrystallines.

The following subjects are included: tool fracture; thermal cracking; crack initiation and growth; failure and damage in cutting tools; tool wear; fatigue fracture; tool flank wear; diffusion wear; cracks in brittle materials; fracture probability; delamination of composites during machining; shear localization and ductile fracture.

The cutting tool materials analysed are: steel; ceramic tools; cemented-carbide tools; boride-cement tools; diamond; ceramics resin concrete; sintered carbide; aluminium oxide tools.

\section{Chip formation mechanism}

Metal cutting is a chip-formation process. The problem of chip formation and its control has been studied by trying to define the mechanism of chip formation, chip flow and chip breaking. The parameters involved are the tool and workpiece materials (type, strength, hardness, shape), the cutting data (feed, cutting depth and speed), the tool geometry, the cutting geometry, etc. The character of the movement of the chip along the contact length with the tool is another important factor. Most of the heat generated in machining is removed from the cutting zone by the chip. Chip control is necessary, especially in turning and drilling. Milling creates a natural chip length due to the limited length of cutting edge engagement.

To numerically simulate the chip formation mechanism during the machining process is not an easy task. There are too many complicated factors to be taken into account: contact and work material deformation with large plastic strains and friction, high temperature effects, strain-rate and strain hardening effects. 
The topics in chip-formation processes include: chip formation in orthogonal machining; chip formation in high-speed machining; chip formation in microcutting; chip formation in interrupted turning; chip formation in oblique cutting; 3D continuous chip formation; segmental chip formation; serrated chip formation; chip separation; chip breaking; shear localization in chip formation; chip flow and tool wear; chip-tool interface contact problems.

\section{Optimization and other topics}

In this last section, optimization problems arising in machining are handled. Specifically: tool-shape optimization; machine-shape foundation optimization; optimization of a milling cutter; lathe bed optimization; optimum fixture design; optimum design of an abrasive disk; optimum design of a radial drilling machine; optimum drill geometry; optimum design of a lathe spindle; optimization of the functional properties of machines; and optimization problems in electrochemical machining.

Other topics where the finite-element technique has been implemented include: CAD and machining; computer graphics and machining; virtual engineering in machine tool design; error compensation in machine tools; validation of finite-element codes; and cuttingforce measurement.

\section{Acknowledgements}

The bibliography presented in the Appendix is by no means complete but it gives a comprehensive representation of different finite-element applications on the subjects. The author wishes to apologise for the unintentional exclusions of missing references and would appreciate receiving comments and pointers to other relevant literature for a future update.

\section{References}

[1] R.A. Walsh, McGraw-Hill Machining and Metalworking Handbook, McGraw-Hill, New York, 1994.

[2] J.R. Davis, et al. (Eds.), Machining, Metals Handbook, vol. 16, ASM, Metals Park, OH, 1989.

[3] J. Mackerle, MAKEBASE, an information retrieval system in structural mechanics for main-frames and personal computers, Eng. Comput. 6 (1989) 178-185.

[4] J. Mackerle, An information retrieval system for finite element and boundary element literature and software, Eng. Anal. Boundary Elem. 11 (1993) 177-187.

[5] J. Mackerle, Finite Element Methods, A Guide to Information Sources, Elsevier, Amsterdam, 1991.

\section{Appendix A. A bibliography (1976-1996)}

This bibliography provides a list of literature references on finite-element applications in machining. The presented listings contain papers published in scientific journals, conference proceedings, and theses/dissertations, retrospectively to 1976 . References have been retrieved from the author's database, MAKEBASE. The COMPENDEX database, Metals abstracts and Applied Mechanics Review have also been checked. The references presented are grouped into the same sections as listed in the first part of this paper.

The emphasis of this bibliography is to list, first of all, papers published in various international journals. There have been numerous national and international conferences and symposia held worldwide, but conference proceedings are a source of never-ending bibliographical confusion. No review on conference proceedings can ever be comprehensive. The main criticism of conferences is that the material presented is often a repetition of what is published elsewhere in the literature, and also the complaint of uneven quality of papers is often heard. Surveys have shown low usage of published conference proceedings in practice. Also, many important conference papers are published afterwards in an edited version in international journals.

References are not arranged chronologically but sorted in each category alphabetically according to the first author's name. If a specific paper is relevant for several subject categories, the same reference can be listed under respective section headings.

\section{A.1. Material removal and cutting processes in general}

[1] A. Abdali, K. Benkrid, P. Bussy, Numerical simulation of sheet cutting, in: S.F. Shen, P. Dawson (Eds.), NUMIFORM 95, Balkema, Rotterdam, pp. 807-813 (1995).

[2] A. Abdel Hamid, A.S. Wifi, M. El Gallab, A three dimensional finite element thermomechanical analysis of intermittent cutting process, J. Mater. Process. Tech. $56(1 / 4)(1996) 643-654$.

[3] N. Aeby, An example of finite element analysis in the conception of machine tools, in: R.S. Sodhi (Ed.), Advanced Manufacturing Systems, Elsevier, Amsterdam, 1994, pp. 423-428.

[4] M.M. Ahmad, W.A. Draper, R.T. Derricott, The application of the finite-element method in the prediction of cutting tool performance, in: C.A. Brebbia (Ed.), Boundary Elements VII, vol. 2, Springer, Berlin, 1985.

[5] M.M. Ahmad, W.A. Draper, R.T. Derricott, An application of the finite element method to the prediction of cutting tool performance, Int. J. Machine Tools Manuf. 29 (2) (1989) 197-206. 
[6] C.A. Anderson, Material removal processes: engineering mechanics consideration, in: Principal Cutting Mechanisms: Applied Ultra-Precision, ASPE, Tucson, AZ, 1993, pp. 5-8.

[7] N. Arai, et al., A study on the cutting of quenched steel by tool having negative rake angle, Sci. Eng. Rev. Doshisha Univ. 33 (3) (1992) 185-198.

[8] V.G. Atapin, Calculation of the deformed state of the foundation of a heavy multipurpose machine tool, Sov. Eng. Res. 9 (6) (1989) 41-43.

[9] S. Bartsch, Stress calculations for ceramic cutting tips based on the finite element method, Ind. Anz. 108 (37) (1986) 43-44.

[10] S.B. Bell, The deformation of carbide cutting tools, PhD Thesis, University of Durham, UK, 1988.

[11] S.B. Billatos, A.S. Ayad, Innovative approach to environmentally safe machining, in: International Mechanical Engineering Congress Exposition DE 74, ASME, New York, 1994, pp. 1-8.

[12] G.T. Camacho, T.D. Marusich, M. Ortiz, Modelling of high-speed machining and ballistic penetration, in: D.R.J. Owen (Ed.), Fourth International Conference Comp. Plast., Pineridge Press, 1995, pp. 1835-63. [13] J.T. Carroll, A numerical and experimental study of single point diamond machining, PhD Thesis, North Carolina State University, 1987.

[14] J.T. Carroll, J.S. Strenkowski, Finite element models of orthogonal cutting with application to single point diamond turning, Int. J. Mech. Sci. 30 (1988) 899-920.

[15] J.F.L. Chan, P.M. Braiden, The calculation of stresses in cutting tools, Applied Solid Mechanics, E1sevier, Amsterdam, 1986, pp. 245-254.

[16] H.L. Chen, T.F. Lehnhoff, M. Doraivelu, A stress ratio parameter for studying the workability of metalstension and compression, J. Mater. Shaping Tech. 8 (2) (1990) 111-122.

[17] H.L.H. Chen, Intrinsic workability and metal forming analysis, $\mathrm{PhD}$ Thesis, University of MissouriRolla, 1990.

[18] Z.G. Chen, J.T. Black, FEM modeling in metal cutting, Manuf. Rev. 7 (2) (1994) 120-133.

[19] S.Y. Chern, An improved finite element model of orthogonal cutting with special emphasis on shear zones, PhD Thesis, North Carolina State Univeristy 1992.

[20] T.H.C. Childs, Contact stresses in metal machining, in: A.D. Robert (Ed.), Contact Stress Analysis, IOP, 1990, pp. 49-62.

[21] M.A. Dokainish, M.A. Elbestawi, U. Polat, B. Tole, Analysis of stresses during exit in interrupted cutting with chamfered tools, Int. J. Machine Tools Manuf. 29 (4) (1989) 519-534.

[22] K.W. Dunlop, U.P. Singh, Finite element analysis of press tool, in: Thirtieth International Matador Conference, Manchester, 1993, pp. 477-484.
[23] L. Fourment, et al., Incremental mass conservation and adaptive remeshing for the thermo-mechanical coupling between workpiece and tool in non steady metal forming, in: S.F. Shen, P. Dawson (Eds.), NUMIFORM 95, Balkema, Rotterdam, 1995, pp. 431-434. [24] J.L. Frater, G.J. Petrus, Combining finite element methods and the Cockcroft and Latham criteria to predict free surface workability of cold forgings, in: Transactions North American Manufacturing Research Institute, SME, 1990, pp. 97-102.

[25] J.C. Hamann, V. Grolleau, F. Le Maitre, Machineability improvement of steels at high cutting speedsstudy of tool/work material interaction, Ann. CIRP 45 (1996) 87-92.

[26] S. Hanasaki, M. Nomura, Analysis of carbon-fiberreinforced plastic cutting mechanism by finite element method (fracture behavior of fiber at entry of cutting), Trans. Jpn. Soc. Mech. Eng., Ser C 61 (583) (1995) $1163-68$.

[27] S. Hanasaki, et al., Analysis of CFRP cutting by finite element method, Int. J. Jpn. Soc. Prec. Eng. 28 (4) (1994) 340-342.

[28] J. Hashemi, A.A. Tseng, P.C. Chou, Finite element modeling of high-speed orthogonal cutting process, in: First International Conference Process. Mater. Prop., Honolulu, 1993, pp. 49-53.

[29] M. Hashimura, S. Katayama, An analysis of the cutting force in interrupted cutting processes using a three dimensional finite element method, in: Mater. Issues Machining II, AIME, Chicago, 1994, pp. 77-88. [30] M. Hashimura, K. Ueda, D. Dornfeld, K. Manabe, Analysis of three-dimensional burr formation of oblique cutting, Ann. CIRP 44 (1) (1995) 27-30.

[31] M.W. Heinstein, Simulation of shear band phenomenon in metal forming and cutting, $\mathrm{PhD}$ Thesis, Purdue University, 1991.

[32] U. Heisel, H. Yuan, V. Maier, Modular structure of FE model for the calculation of cutting machine tool spindles, Konstruktion 47 (11) (1995) 358-362.

[33] D.H. Howerton, An experimental and numerical investigation of orthogonal machining of aluminum 6061-T6, PhD Thesis, North Carolina State University, 1989.

[34] J.M. Hsu, A three-dimensional finite element model of metal cutting, PhD Thesis, North Carolina State University, 1991.

[35] T.W. Hwang, Analysis of surface quality in machining of metals and advanced ceramics, $\mathrm{PhD}$ Thesis, University of Maryland, College Park, 1992.

[36] T.W. Hwang, G. Zhang, Analysis of elastoplastic deformation observed on machined surfaces, Wint. Annu. Meet., New Orleans, PED 64, ASME (1993) $553-562$.

[37] K. Iwata, et al., Analysis of microscopic behavior of tungsten carbide cutting tool materials by finite element method, J. Jpn. Soc. Precis. Eng. 47 (1981) $1451-57$. 
[38] V.S. Joshi, P.M. Dixit, V.K. Jain, Viscoplastic analysis of metal cutting by finite element method, J. Mater. Process. Technol. 34 (4) (1994) 553-571.

[39] Y. Kadowaki, Analysis of chucking pressure distribution in considerations of joints, Trans. Jpn. Soc. Mech. Eng., Ser C 51 (1985) 2180-2187.

[40] K.W. Kim, H.C. Sin, Development of a thermoviscoplastic cutting model using finite element method, Int. J. Machine Tools Manuf. 36 (3) (1996) 379-398. [41] Y. Kita, M. Ido, N. Kawasaki, A study of metal flow ahead of tool face with large negative rake angle, J. Eng. Ind., ASME 104, (1982) 319-325.

[42] B.E. Klamecki, S. Kim, On the plane stress to plane strain transition across the shear zone in metal cutting, J. Eng. Ind., ASME 110 (1988) 322-325.

[43] K. Komvopoulos, S.A. Erpenbeck, Finite element modeling of orthogonal metal cutting, in: B. Singh (Ed.), Comp. Model. Simul. Manuf. Proc., MD 20, ASME, 1990, pp. 1-23.

[44] K. Komvopoulos, S.A. Erpenbeck, Finite element modeling of orthogonal metal cutting, J. Eng. Ind., ASME 113 (3) (1991) 253-267.

[45] A. Kumabe, K. Yamamoto, K. Sekiya, R. Kitagawa, Behavior of cutting strain in vicinity of entrance and end of cut in aluminum by photoelastic coating method, Trans. Jpn. Soc. Mech. Eng., Ser C 61 (584) (1995) 1703-1708.

[46] M.R. Lajczok, A study of some aspects of metal machining using the finite element method, PhD Diss., North Carolina State University, 1980.

[47] K. Lange, H.J. Keller, Some aspects of the economic production of complex steel components by cold forging and machining, J. Mater. Process. Technol. 46 (1/2) (1994) 239-251.

[48] J. Leopold, U. Semmler, G. Schmidt, K. Hoyer, Determining cutting tool boundary loads using the finite element method and the method of viscoplasticity, Wiss. Z. Tech. Hochschule Karl-Marx-Stadt 27 (4) (1985) 615-622.

[49] J. Leopold, U. Semmler, B. Braunlich, K. Heincke, Application of the method of finite elements to the calculation of restraining force in a billet cutter, Umform Technol. 20 (2) (1986) 77-83.

[50] Z.C. Lin, S.Y. Lin, A coupled finite element model of thermo-elastic-plastic large deformation for orthogonal cutting, J. Eng. Mater. Technol., ASME 114 (2) (1992) 218-226.

[51] Z.C. Lin, C.C. Liu, Finished machining simulation with a pseudo-friction coefficient, J. Chin. Soc. Mech. Eng. 16 (3) (1995) 257-268.

[52] Z.C. Lin, W.C. Pan, A thermoelastic-plastic large deformation model for orthogonal cutting with tool flank wear-Part I: Computational procedures, Int. J. Mech. Sci. 35 (10) (1993) 829-840.

[53] Z.C. Lin, W.C. Pan, A thermoelastic-plastic large deformation model for orthogonal cutting with tool flank wear-Part II: Machining application, Int. J. Mech. Sci. 35 (10) (1993) 841-850.

[54] Z.C. Lin, W.C. Pan, A thermo-elastic-plastic model with special elements in a cutting process with tool flank wear, Int. J. Mach. Tools Manuf. 34 (6) (1994) 757-770.

[55] Z.C. Lin, W.C. Pan, S.P. Lo, Study of orthogonal cutting with tool flank wear and sticking behavior on the chip-tool interface, J. Mater. Process. Technol. 52 (2/4) (1995) 524-538.

[56] K.J. Lindblom, Computer aided surface development and manufacturing methods, SAE Trans. (1985) 851117.

[57] C.R. Liu, Z.C. Lin, Effects of shear plane boundary condition on stress loading in orthogonal machining, Int. J. Mech. Sci. 27 (1985) 281-290.

[58] S.D. Madnaik, R.C. Chaturvedi, A finite-element solution to the problem of plane-strain compression of pre-shaped material with inclined tools, in: K. Mattiasson, et al. (Eds.), NUMIFORM 86, Balkema, Rotterdam, 1986, pp. 139-144.

[59] K. Maekawa, T. Nagayama, I. Ohshima, R. Murata, Finite element simulation of oblique cutting, Bull. Jpn. Soc. Precis. Eng. 24 (3) (1990) 221-222.

[60] K. Maekawa, T. Nagayama, I. Ohshima, R. Murata, Finite element simulation systems for metal machining. III-Extension from two-dimensional to three-dimensional analysis, J. Fac. Eng., Ibaraki Univ. (40) (1992) 131-144.

[61] R.P. Maisch, Description of contact and friction between workpiece and tool for the FE simulation of forming processes, PhD Thesis, Eidgen. Tech. Hochschule, Zurich, 1993.

[62] K. Manabe, K. Ueda, S., Tomiyama, Rigid-plastic FEM analysis of three-dimensional cutting mechanism. Chip formation mechanism in oblique cutting, J. Jpn. Soc. Precis. Eng. 59 (10) (1993) 1701-1706.

[63] T.D. Marusich, M. Ortiz, Finite element simulation of high-speed machining, 1994 International Mechanical Engineering Congress Exposition AMD 194, ASME, 1994, pp. 137-149.

[64] T.D. Marusich, M. Ortiz, Simulation of high-speed machining, in: T.J.R. Hughes (Ed.), Rec. Dev. Finite Elem. Anal., CIMNE, 1994, pp. 62-77.

[65] T.D. Marusich, M. Ortiz, Modelling and simulation of high-speed machining, Int. J. Num. Meth. Eng. 38 (21) (1995) 3675-3694.

[66] T.D. Marusich, M. Ortiz, Finite element simulation of high-speed machining, in: S.F. Shen, P. Dawson (Eds.), NUMIFORM 95, Balkema, Rotterdam, 1995, pp. $101-108$.

[67] J. Monaghan, M. Murphy, Analysis of the stress distribution within the layers of multi-coated forming and cutting tools, Key Eng. Mater. 118-119 (1996) $131-138$. 
[68] N. Morita, Y. Yoshida, Brittle-ductile transition and its control in machining of monocrystal siliconanalysis of transition mechanism by sliding contact model, J. Ceram. Soc. Jpn. 102 (1994) 1137-1141.

[69] J.R. Murthy, G.C. Reddy, Floating hinge in machine tool structures - finite element representation, Comput.-Aided Des. 15 (1983) 201-208.

[70] T. Obikawa, E. Usui, Computational machining of titanium alloy- finite element modeling and a few results, J. Manuf. Sci. Eng., ASME 118 (2) (1996) $208-$ 215.

[71] T. Obikawa, et al., Embrittlement action of free machining additives (2nd Rep-Estimation of stressstrain curve of resulfurized steel based on $\mathrm{MnS}$ particles' actions), J. Jpn. Soc. Precis. Eng. 53 (1987) 1057-1063.

[72] T. Obikawa, et al., Finite element analysis of polymer cutting - cutting simulation of polyvinyl chloride, J. Jpn. Soc. Precis. Eng. 53 (1987) 288-294.

[73] T. Obikawa, T. Shirakashi, E. Usui, FEM analysis on FRP cutting, J. Jpn. Soc. Precis. Eng. 57 (6) (1991) 1029-1034.

[74] T. Obikawa, J. Shinozuka, T. Shirakashi, Analytical prediction of cutting performances of grooved rake face tools, J. Jpn. Soc. Precis. Eng. 61 (9) (1995) 1295-99.

[75] H. Okamoto, M. Tsutsumi, Y. Ito, Determination of mathematical model in structural analysis of machine tools, model of basic structural component using rigidity distribution diagram, Bull. JSME 24 (193) (1981) 1288-1294.

[76] D.T. Pham, A.D. Lazaro, Finite element study of a workpiece in a machining fixture, Math. Comp. Modell. 14 (1990) 1024-1028.

[77] J. Pierry, X.C. Wang, Finite element modelling of strain localization in shear bands during a cutting process, in: Local. Damage III, CMP, Udine, 1994, pp. $521-527$.

[78] R. Rakotomalala, P. Joyot, M. Touratier, Arbitrary Lagrangian-Eulerian thermomechanical finite-element model of material cutting, Commun. Num. Meth. Eng. 9 (12) (1993) 975-987.

[79] S.S. Rao, C.P. Reddy, Reliability analysis of machine tool structures, J. Eng. Industry, ASME 99 (4) (1977) 882-888.

[80] A.B. Sadat, M.Y. Reddy, B.P. Wang, Plastic deformation analysis in machining of Iconel-718 nickel-base superalloy using both experimental and numerical methods, Int. J. Mech. Sci. 33 (10) (1991) 829-842.

[81] H. Sasahara, T. Obikawa, T. Shirakashi, FEM analysis on three dimensional cutting- analysis on large deformation problem of tool entry, J. Jpn. Soc. Precis. Eng. 59 (8) (1993) 1275-1280.

[82] H. Sasahara, T. Obikawa, T. Shirakashi, Analytical prediction of the characteristics within machined surface layer (Part 3-The thermal and mechanical effects on machined surface), J. Jpn. Soc. Precis. Eng. 60 (12) (1994) 1801-1805.

[83] H. Sasahara, T. Obikawa, T. Shirakashi, Change of mechanical characteristics in machined layer with machining sequence, J. Jpn. Soc. Precis. Eng. 61 (10) (1995) 1453-1457.

[84] H. Sashara, T. Obikawa, T. Shirakashi, Finite element method on 3D cutting: analysis on large deformation problem of tool entry, Int. J. Jpn. Soc. Prec. Eng. 28 (2) (1994) 123-128.

[85] M. Sato, T. Yamazaki, N. Masui, H. Akai, Y. Kato, Simulate analysis on creation process of finished surface with diamond cone stylus, Trans. Jpn. Soc. Mech. Eng., Ser C 51 (1985) 1588-1595.

[86] M. Sato, T. Yamazaki, N. Masui, H. Akai, Simulation analysis of creation process of finished surface with diamond cone stylus, Bull. JSME 29 (249) (1986) 10181025.

[87] G.S. Sekhon, J.L. Chenot, Some simulation experiments in orthogonal machining, in: J.L. Chenot (Ed.), Num. Meth. Ind. Form. Process., Balkema, Rotterdam, 1992, pp. 901-906.

[88] K. Sekiya, R. Kitagawa, Correspondence of the stress analysis of chamfered cutting tools by the finite element method with the tool failure in interrupted cutting, Mem. Fac. Eng., Yamaguchi Univ. 41 (2) (1991) 35-42.

[89] A.J. Shih, Finite element simulation of orthogonal metal cutting, J. Eng. Industry, ASME 117 (1) (1995) $84-93$.

[90] A.J. Shih, Finite element analysis of orthogonal metal cutting mechanics, Int. J. Mach. Tools Manuf. 36 (2) (1996) 255-274.

[91] A.J.M. Shih, Experimental and finite element simulation methods for metal forming and cutting process, PhD Thesis, Purdue University, 1991.

[92] A.J.M. Shih, S. Chandrasekar, H.T.Y. Yang, Finite element simulation of metal cutting process with strain-rate and temperature effects, Winter Annu. Meet., Dallas, PED 43, ASME (1990) 11-24.

[93] T. Shimizu, T. Sano, Application of a penalty method contact and friction algorithm to a 3-dimensional tool surface expressed by a B-spline patch, J. Mater. Process. Technol. 48 (1/4) (1995) 207-213.

[94] W. Shimotsuchibashi, K. Ueda, Development of analytical simulator for prediction of machining error due to elastic deformation of clamped work, J. Jpn. Soc. Precis. Eng. 57 (3) (1991) 453-458.

[95] T. Shirakashi, M. Yoshino, Simulation of cutting process of single crystal aluminum, J. Jpn. Soc. Precis. Eng. 25 (3) (1991) 181-186.

[96] B. Singh, et al. (Eds.), Computer Modeling and Simulation of Manufacturing Processes, Winter Annual Meeting, ASME, 1990.

[97] K. Skalski, A. Morawski, W. Przybylski, Analysis of contact elastic-plastic strains during the process of burnishing, Int. J. Mech. Sci. 37 (5) (1995) 461-472. 
[98] J.S. Strenkowski, Designing tools with FEA, Mach. Design 58 (12) (1986) 63-65.

[99] J.S. Strenkowski, J.T. Carroll, A finite element model of orthogonal metal cutting, J. Eng. Ind., ASME 107 (1985) 349-354.

[100] J.S. Strenkowski, J.T. Carroll, An orthogonal metal cutting model based on an Eulerian finite element method, in: Thirteenth NSF Conference Prod. Res. Tech., 1986, pp. 261-264.

[101] M. Tsutsumi, K. Nakai, Y. Anno, Static characteristics of $7 / 24$ tapered joint in machining centers, Trans. Jpn. Soc. Mech. Eng., Ser C 51 (1985) 16291637.

[102] T.C. Tszeng, W.T. Wu, J.P. Tang, Prediction of distortion during heat treating and machining processes, in: Sixteenth Conference Heat Treat., Cincinnati, ASM, 1996, pp. 9-15.

[103] M.J. Twu, Metalworking analysis by the finite element method, PhD Thesis, The University of Texas, Arlington, 1991.

[104] T. Tyan, W.H. Yang, Analysis of orthogonal metal cutting processes, Int. J. Num. Methods Eng. 34 (1) (1992) 365-389.

[105] E. Usui, et al., Embrittlement action on pre-machining additives- model analysis of plastic flow and void formation around additive particle, J. Jpn. Soc. Precis. Eng. 46 (1980) 849-855.

[106] E. Usui, K. Maekawa, T. Shirakashi, Simulation analysis of built-up edge formation in machining of low carbon steel, J. Jpn. Soc. Precis. Eng. 47 (1981) 197203.

[107] B.P. Wang, A.B. Sadat, M.J. Twu, Finite element simulation of orthogonal cutting - a survey, in: Winter Annu. Meet. MD 8, ASME (1988) 87-91.

[108] M. Weck, A. Heinmann, Analysis of variants of machine tool structures by means of the finite element method, in: International Machine Tool Design Research Conference, Macmillan, London, 1978, pp. 553559.

[109] N.M. Werfalli, A study of the instantaneous deformation using combined viscoplasticity, flow function, and finite element method, PhD Thesis, Queen's University at Kingston, Canada, 1990.

[110] A.S. Wifi, E.A. Orady, Finite element applications in manufacturing processes: an overview, in: Current Advances in Mechanical Design Product, Pergamon, Oxford, 1986, pp. 417-432.

[111] J.S. Wu, O.W. Dillon, W.Y., Lu, Thermo-viscoplastic modeling of machining process using a mixed finite element method, in: Winter Annu. Meet., Anaheim, MD 39, ASME (1992) 113-128.

[112] H.M. Zbib, et al., On the localization of plastic deformation during metal forming and cutting processes, in: Third World Congress Comp. Mech., Chiba, Japan, 1994, pp. D14-2.
[113] J.M. Zhou, P.O. Sturesson, H. Sandqvist, J.E. Stahl, An approach for on-line cutting edge stress estimation, Int. J. Machine Tools Manuf. 34 (5) (1994) $741-751$.

[114] C.L. Zone, C.P. Wen, P.L. Ship, Study of orthogonal cutting with tool flank wear and sticking behavior on the chip-tool interface, J. Mater. Process. Technol. $52(2 / 4)(1995) 524-538$.

\section{A.2. Computational models for specific machining processes}

\section{A.2.1. Turning}

[1] X. Ai, C. Xia, Study on the criterion for ceramic tool fracture in intermittent steel turning, Chin. J. Mech. Eng. 3 (1) (1990) 1-8.

[2] J.T. Carroll, J.S. Strenkowski, Finite element models of orthogonal cutting with application to single point diamond turning, Int. J. Mech. Sci. 30 (1988) 899-920. [3] T.H.C. Childs, K. Maekawa, Computer-aided simulation and experimental studies of chip flow and tool wear in the turning of low alloy steels by cemented carbide tools, Wear 139 (2) (1990) 235-250.

[4] T.I. El-Wardany, E. Mohamed, M.A. Elbestawi, Material side flow in finish turning of hardened steel with ceramic tools, in: Winter Annu. Meet., New Orleans, PED 67, ASME (1993) 159-170.

[5] G.D. Hiatt, A fracture mechanics technique for predicting the ductile regime in single point diamond turning of brittle materials, PhD Thesis, North Carolina State University, 1992.

[6] T. Ihara, et al., Analytical prediction of cutting edge chipping in interrupted turning operation-transient distributions of temperature and thermal stress, J. Jpn. Soc. Precis. Eng. 48 (1982) 757-763.

[7] C.L. Liao, Y.S. Tarng, Dynamic response of a workpiece in turning with continuously varying speed, Comput. Struct. 45 (5/6) (1992) 901-909.

[8] Y. Morimoto, T. Yasui, T. Inamura, Compensation of form deviation in NC lathe machining, J. Jpn. Soc. Precis. Eng. 57 (10) (1991) 1757-1762.

[9] T. Moriwaki, K. Yokoyama, C. Zhao, Improving machining accuracy in turning with use of tool holder made of Super-Invar, in: International Mechanical Engineering Congress Exh. MECH '91, Sydney, 1991, pp. $88-92$.

[10] J.R. Murthy, G.C. Reddy, Floating hinge in machine tool structures-finite element representation, Comp.-Aided Des. 15 (1983) 201-208.

[11] M. Rahman, M.A. Mansur, Development and evaluation of ferrocement legs for a lathe, Int. J. Mach. Tools Manuf. 30 (4) (1990) 629-636.

[12] T. Shirakashi, E. Usui, Analytical prediction of time dependency of chipping occurrence in interrupted turning operation, in: First International Metal Cutting Conference, China Acad., 1985, pp. 243-261. 
[13] J.S. Strenkowski, G.D. Hiatt, Technique for predicting the ductile regime in single point diamond turning of brittle materials, in: Winter Annu. Meet., Dallas, PED 43, ASME (1990) 67-80.

[14] E. Usui, et al., Analytical prediction of cutting edge chipping in interrupted turning operation-distributions of impact stress and fracture probability, J. Jpn. Soc. Precis. Eng. 46 (1980) 983-989.

[15] E. Usui, et al., Analytical prediction of cutting edge chipping in interrupted turning operation (7th RepVariation of probability of edge failure), J. Jpn. Soc. Precis. Eng. 50 (1984) 866-874.

[16] A. Waked, R.K. Al-Abbas, M.M. Sadek, Thermal behaviour of bonded carbide tipped turning tool during cutting, Ind. J. Technol. 29 (11) (1991) 513-518.

[17] M.F. Walter, J.E. Stahl, Connection between cutting and clamping forces in turning, Int. J. Mach. Tools Manuf. 34 (7) (1994) 991-1003.

\section{A.2.2. Milling}

[18] Y. Altintas, D. Montgomery, E. Budak, Dynamic peripheral milling of flexible structures, in: B. Singh (Ed.), Comput. Model. Simul. Manuf. Proc., MD 20, ASME, 1990, 25-35.

[19] Y. Altintas, D. Montgomery, E. Budak, Dynamic peripheral milling of flexible structures, J. Eng. Ind., ASME 114 (2) (1992) 137-145.

[20] G. Bianchi, F. Paolucci, P. Van den Braembussche, $\mathrm{H}$. Van Brussel, Towards virtual engineering in machine tool design, Ann. CIRP 45 (1996) 381-384.

[21] S.K. Choudhury, J. Mathew, Investigations of the effect of nonuniform insert pitch on vibration during face milling, Int. J. Mach. Tools Manuf. 35 (10) (1995) 1435-1444.

[22] J.N. Dube, Comparison of computer and model techniques for dynamic analysis of milling machine structure, in: Second Nat. Machine Design Prod. Congress, METU, Ankara, 1986.

[23] J.N. Dube, Computer-aided design of machine-tool structure with model techniques, Comput. Struct. 28 (1988) 345-352.

[24] M.A. Elbestawi, R. Sagherian, Dynamic modeling for the prediction of surface errors in the milling of thin-walled sections, J. Mater. Process. Technol. 25 (2) (1991) 215-228.

[25] K. Honda, T. Torii, Z. Fei, Analysis and measurements of residual stress redistribution due to material removal in a plate, in: Thirty-second Japanese Congress on Mater. Res. Soc. Mat. Sci., 1989, pp. 134-141.

[26] N. Inoue, et al., Development of a high strength mill spindle and consideration of strength evaluation method for the spindle, Kawasaki Steel Giho 16 (3) (1984) 221-231.

[27] C. Ispas, C. Dogariu, C. Mohora, Research on machine tools bed dynamic behavior, Mech. Ind. Mater. 47 (4) (1994) 445-447.
[28] N.K. Jha, K. Hornik, Integrated computer aided optimal design and finite element analysis of a plain milling cutter, Appl. Math. Model. 19 (6) (1995) 343353.

[29] N.L. Keller, M.S. Lesonick, Vibration analysis of stand F2 of wheeling-Pittsburgh's 80-in hot strip mill, Iron Steel Eng. 67 (5) (1990) 17-22.

[30] J. Kratky, J. Sima, Calculation of column of type W $180 \mathrm{NC}$ horizontal boring and milling machine by finite element method, Skoda Rev. (4) (1986) 40-44. [31] H.Y. Lai, Computer aided milling machine modal analysis, in: Fourth International Modal Conference, Los Angeles, Union College, 1986, pp. 1140-1148.

[32] S.J. Lee, S.G. Kapoor, Cutting process dynamics simulation for machine tool structure design, J. Eng. Ind., ASME 108 (1986) 68-74.

[33] S.J. Lee, S.G. Kapoor, Integrated process and structural optimization for face milling systems, in: R.P. Shaw (Ed.), Innov. Num. Meth. Engng., Springer, Berlin, 1986, pp. 513-518.

[34] C.L. Liao, J.S. Tsai, Dynamic response analysis in end milling using pre-twisted beam finite elements, J. Mater. Process. Technol. 40 (3/4) (1994) 407-432.

[35] C.L. Liao, J.S. Tsai, Dynamic response analysis in end milling using pretwisted beam finite element, J. Vib. Acoust., ASME, 117 (1) (1995) 1-10.

[36] H.R. Lii, et al., A dynamic mechanistic model of cutting forces in end milling, in: Eighth National Conference, CSME, Taipei, Taiwan, 1991, pp. 1001-1010. [37] J. Lin, Inverse estimation of the tool-work interface temperature in end milling, Int. J. Mach. Tools Manuf. 35 (5) (1995) 751-760.

[38] K.J.J. Liu, Vibration control of cutting process in milling using dynamic absorber, PhD Thesis, University of Kentucky, 1993.

[39] H.R. Ludwig, Determining the stresses on milling cutters- analysis using the finite element method, Werkstattstech. Z. Ind. Fertigung 80 (8) (1990) 429-431.

[40] H.R. Ludwig, Tool cutting by end milling - bases of a finite element method analysis of stress, Werkstattstech. Z. Ind. Fert. 80 (7) (1990) 353-356.

[41] S. Ohta, Improvement of reliability of designing mill housing, J. Iron Steel Inst. Jpn. 80 (3) (1994) T49-51.

[42] S. Ram, J.N. Dube, Analysis of a milling machine structure for ribbing of the cross-arm, Comput. Struct. 30 (1988) 1355-1358.

[43] G.V. Ramana, S.S. Rao, Optimum design of plano-milling machine structure using finite element analysis, Comput. Struct. 18 (2) (1984) 247-253.

[44] T.D. Sachdeva, C.V. Ramakrishnan, Out-of-plane flexibilities of dovetail joints in machine tool structures, Comput. Struct. 17 (4) (1983) 529-538.

[45] K. Sawada, K. Imai, Y. Takeuchi, T. Sata, Development of ultraprecision machining center with closedloop structure and its control, Ann. CIRP 44 (1) (1995) 369-372. 
[46] T. Shi, et al., Dynamic modeling of face mill arbor and turning tool support assembly for tool condition monitoring, in: Fifteenth NAMRC, Lehigh University, Bethlehem, PA, 2, 1987, pp. 469-476.

[47] H.K. Toenshoff, B. Denkena, Wear of ceramic tools in milling, Lubric. Eng. 47 (9) (1991) 772-778. [48] K. Ueda, K. Manabe, S. Nozaki, Rigid-plastic FEM analysis of three-dimensional cutting mechanism (2nd Rep, Simulation of plain milling process), J. Jpn. Soc. Precis. Eng. 62 (4) (1996) 526-530.

[49] M. Vacance, et al., Multi stand pipe mill finite element model, J. Mater. Process. Technol. 24 (1990) 421-430.

[50] Z.Y. Wang, C. Sahay, K.P. Rajukar, Tool temperatures and crack development in milling cutters, Int. J. Mach. Tools Manuf. 36 (1) (1996) 129-140.

[51] D.C. Webb, K. Kormi, The design and analysis of helical milling cutters using integrated FEA packages, in: J.T. Boyle (Ed.), Finite Elem. Anal.: Educ. Train., Elsevier, Amsterdam, 1991, pp. 173-190.

[52] M. Weck, E. Eich, R. Finke, Determination of the dynamic behavior of a crankshaft milling unit, Werkstattstechnik 67 (3) (1977) 155-160.

\section{A.2.3. Drilling}

[53] J.S. Agapiou, M.F. De Vries, On the determination of thermal phenomena during drilling. I-Analytical models of twist drill temperature distributions, Int. J. Mach. Tools Manuf. 30 (2) (1990) 203-215.

[54] K. Amemiya, et al., FEM analysis of torsional strength for twist drill, Int. J. Jpn. Soc. Prec. Eng. 29 (1) (1995) 44-46.

[55] N. Arai, et al., Study on low frequency vibratory drilling of SUS304 (Cutting temperature of drill point), Trans. Jpn. Soc. Mech. Eng., Ser C 56 (527) (1990) $1960-1964$.

[56] W. Arnold, et al., Numerical determination of the residual stress in machined surfaces, Wiss. Z. Tech. Hochsch. Karl-Marx-Stadt 27 (5) (1985) 768-772.

[57] M. Beghini, L. Bertini, P. Raffaelli, Numerical analysis of plasticity effects in the hole-drilling residual stress measurement, J. Test Eval. 22 (6) (1994) $522-$ 529.

[58] M. Beghini, L. Bertini, P. Raffaelli, Account of plasticity in the hole-drilling method of residual stress measurement, J. Strain Anal. Eng. Design 30 (3) (1995) 227-233.

[59] J.M. Boag, M.T. Flaman, J.A. Herring, Considerations of using the hole drilling method for measuring residual stresses in engineering components, in: W.B. Young (Ed.), Res. Str. Des. Proc. Mat. Sel., ASM, 1987, pp. 1-9.

[60] W.C. Chen, Effect of the cross-sectional shape design of a drill body on drill temperature distributions, Int. Commun. Heat Mass Transf. 23 (3) (1996) 355366.
[61] W.C. Chen, et al., Twist drills with special profiles, Z. Wirtsch. Fabr. 90 (5) (1995) 226-228.

[62] K.H. Fuh, Computer aided design and manufacturing for multifacet drills, PhD Thesis, The University of Wisconsin, Madison, 1987.

[63] K.H. Fuh, W.C. Chen, Cutting performance of thick web drills with curved primary cutting edges, Int. J. Mach. Tools Manuf. 35 (7) (1995) 975-991.

[64] K.H. Fuh, W.C. Chen, Temperature rise in twist drills with a finite element approach, Int. Commun. Heat Mass Transf. 21 (3) (1994) 345-358.

[65] R.W. Hampton, D.V. Nelson, On the use of the hole-drilling technique for residual stress measurements in thin plates, J. Press. Vess. Technol., ASME 114 (3) (1992) 292-299.

[66] T.S. Lee, B.K. Choi S.Y. Jeon, H.A. Moon, Measurements of residual stress in the field of the stress gradient by the hole drilling method, in: K.Y. Lee (Ed.), Fract. Strength 90, Trans. Tech. Publ., 1991, pp. 495-500.

[67] Y.H. Lin, et al., Dynamic modeling and analysis of a high speed precision drilling machine, J. Vib. Acoust., ASME, 112 (3) (1990) 355-365.

[68] Y.H. Lin, et al., Modeling of a precision drilling machine with a moving load finite element model and experimental modal data, in: Eighth International Modal Anal. Conference, SEM, 1990, pp. 827-832.

[69] J. Lu, A. Niku-Lari, J.F. Flavenot, The measurement of internal stress distribution in depth by the incremental drilling method, Mem. Etud. Sci. Res. Metall. 82 (2) (1985) 69-81.

[70] J. Lu, A. Niku-Lari, J.F. Flavenot, New developments in the incremental hole-drilling method for measuring residual stress distribution, in: The Effects Fabric. Rel. Str. Prod. Manuf., Weld. Inst., 1987, pp. 137-147.

[71] A. Makino, D. Nelson, Residual stress determination by single-axis holographic interferometry and hole drilling-Part I: Theory, Exp. Mech. 34 (1) (1994) $66-78$.

[72] T. Miyake, et al., Study of mechanism of burr formation in drilling. deformation of material during burr formation, J. Jpn. Soc. Precis. Eng. 57 (3) (1991) 485-490.

[73] R. Natarajan, Analysis of a radial drilling machine structure using finite element method, Comput. Struct. 6 (1976) 55-60.

[74] A.M. Newwar, J.A. Miller, A finite element model of the blind-hole drilling technique, Exp. Mech. 22 (5) (1982) 48-49.

[75] A. Niku-Lari, J. Lu, J.F. Flavenot, Measurement of residual-stress distribution by the incremental holedrilling method, Exp. Mech. 25 (1985) 175-185.

[76] T.M. Niu, P.C. Chen, Finite element stress analysis versus experiments of drills under bending, in: Proceedings of the SEM Spring Conference, Las Vegas, 1985. 
[77] K.E. Prasad, M.A. Rao, R.V. Dukkipati, M. Tummala, Dynamic analysis of radial drilling machine using FEM, in: Wint. Annu. Meet., Anaheim, NCA 14, ASME (1992) 183-194.

[78] F.G. Rammerstorfer, F.D. Fischer, A method for the experimental determination of residual stresses in axisymmetric composite cylinders, J. Eng. Mater. Technol., ASME 114 (1) (1992) 90-96.

[79] S.S. Rao, R.V. Grandhi, Optimum design of radial drilling machine structure to satisfy static rigidity and natural frequency requirements, J. Mech., Transm., Aut. Des., ASME 105 (1983) 236-241.

[80] J. Rotberg, E. Lenz, S. Braun, Vibration-based drill wear monitoring, Manuf. Rev. 3 (1) (1990) 60-65. [81] A.B. Sadat, W.S. Chan, B.P. Wang, Delamination of graphite/epoxy laminate during drilling operation, Compos. Mater. Tech. PD 32, ASME, (1990) 85-88. [82] A.B. Sadat, W.S. Chan, B.P. Wang, Delamination of graphite and epoxy laminate during drilling operation, J. Energy Res. Tech., ASME 114 (2) (1992) 139141.

[83] G.S. Schajer, Measurement of non-uniform residual stresses using the hole-drilling method. Part IIPractical application of the integral method, J. Eng. Mater. Tech., ASME 110 (1988) 344-349.

[84] G.S. Schajer, Measurement of non-uniform residual stresses using the hole drilling method Part II: Practical application of the integral method, Winter Ann. Meet., ASME, MD 7 (1988) 93-99.

[85] S.V.M. Selvam, C. Sujatha, Twist drill deformation and optimum drill geometry, Comput. Struct. 57 (5) (1995) 903-914.

[86] O. Tekinalp, Dynamic modeling of drill bit vibrations, PhD Thesis, The University of Michigan, 1988. [87] O. Tekinalp, A.G. Ulsoy, Effects of geometric and process parameters on drill transverse vibrations, Winter Ann. Meet., ASME, Chicago, PED 33 (1988) 3340.

[88] O. Tekinalp, A.G. Ulsoy Modeling and finite element analysis of drill bit vibrations, in: ASME Des. Technol. Conf., Montreal, ASME, DE 18-2 (1989) 61-68.

[89] O. Tekinalp, A.G. Ulsoy, Effects of geometric and process parameters on drill transverse vibrations, J. Eng. Ind., ASME 112 (2) (1990) 189-194.

[90] M. Tootoonian, G.S. Schajer, Enhanced sensitivity residual-stress measurements using taper-hole drilling, Exp. Mech. 35 (2) (1995) 124-129.

[91] M. Tootoonian, G.S. Schajer, Enhanced sensitivity residual stress measurements using taper hole drilling, in: Fourth International Conference Resid. Stress., Baltimore, SEM, 1994, pp. 52-62.

[92] Y. Tsukano, et al., Optimum design of internal upset geometry of drill pipe for longer fatigue life, Nippon Steel Technol. Rep. (44) (1990) 37-42.
[93] V. Venet, J.P. Henry, D. Fourmaintraux, Contribution to the optimizing of core drilling by modeling the initiation of discing, Rev. Inst. Fr. Pet. 48 (1) (1993) $15-42$.

[94] H. Wern, Measurement of non-uniform residual stresses using the hole drilling method, a new integral formalism, Strain 31 (2) (1995) 63-68.

[95] H. Wern, Finite element solutions for mechanical drilling methods: a new integral formalism, J. Comput. Appl. Math. 63 (1/3) (1995) 365-372.

[96] A. Wijeyewickrema, L.M. Keer, K.F. Ehmann, Drill wandering motion: experiment and analysis, Int. J. Mech. Sci. 37 (5) (1995) 495-509.

\section{A.2.4. Sawing}

[97] J.E. Borchelt, A.G. Ulsoy, P. Papalambros, Efficient computation of band saw blade stresses, J. Mechan., Transm., Autom. Des., ASME 106 (1984) 394-400.

[98] M. Gotoh, M. Yamashita, T.H. Chung, M. Matsuno, Growth behavior of sawtoothed interface and its numerical simulation, J. Soc. Mater. Sci. Jpn. 44 (500) (1995) 570-577.

[99] M. Gotoh, M. Yamashita, T.H. Chung, M. Matsuno, Growth behavior of sawtoothed interface under plane strain compression: compression of similar and dissimilar blocks twinned, J. Soc. Mater. Sci. Jpn. 45 (2) (1996) 169-175.

[100] S. Haranath, et al., Dynamic behaviour of saw blade with applied damping treatment, in: T. Kant (Ed.), Finite Elem. Comp. Mech., Pergamon, Oxford, 1985, pp. 771-780.

[101] N. Nicoletti, D. Fendeleur, L. Nilly, M. Renner, Using finite elements to model circular saw roll tensioning, Holz Roh. Werkst. 54 (2) (1996) 99-104.

[102] A.B. Sadat, W.S. Chan, B.P. Wang, Prediction of edge delamination load in a sawing operation of graphite/epoxy laminate, in: Fourteenth Annu. Energy Sourc. Technol. Conf., ASME, PD 37 (1991) 113-116. [103] W.Z. Wu, Modal testing and analysis in continuous band systems, in: Third International Modal Anal. Conf., Orlando, Union College, 1985, pp. 908-914.

\section{A.2.5. Grinding}

[104] Z.M. Bzymek, G. Song, T.D. Howes, R.E. Garrett, Design of flexible grinding wheel with variable hub thickness, J. Eng. Ind., ASME 116 (2) (1994) 260-262. [105] C.F. Cheng, M.M.F. Yuen, Modelling and simulation of grinding process by finite element method, in: S.F. Shen, P. Dawson (Eds.), NUMIFORM 95, Balkema, Rotterdam, 1995, pp. 827-832.

[106] M.O. Duffy, Heat transfer analysis of the grinding process, PhD Thesis, The University of Connecticut, 1992. 
[107] H. Eda, K. Kishi, Simulation analysis of residual stress distribution in metal grinding, Werkstatt Betreib. 119 (12) (1986) 1019-1024.

[108] H. Eda, et al., Simulation analysis of residual stress in ground surface layer by use of FEM, J. Jpn. Soc. Precis. Eng. 47 (1981) 314-319.

[109] G. Feng, Surface grinding induced phase transformation and residual stresses in $\mathrm{Al}_{2} \mathrm{O}_{3}-\mathrm{ZrO}_{2}$ composites, PhD Thesis, Rutgers State University of New Jersey, 1993.

[110] K.H. Fuh, J.S. Huang, Thermal analysis of creep-feed grinding, J. Mater. Process. Technol. 43 (2/4) (1994) 109-124.

[111] Y. Fukaya, et al., Fabrication of cBN center dot Frit/Al/20/3 center dot frit grinding wheel bonding, Q.J. Jpn. Weld. Soc. 11 (4) (1993) 503-509.

[112] S.M. Gracewski, J.C. Lambropoulos, J.P. Varenne, Dimensional scaling and compliance of tools used in deterministic microgrinding of spherical optics, Proc. SPIE 2536 (1995) 220-230.

[113] K. Homma, Studies on fracture of grinding wheels - effects of pores on strength, J. Jpn. Soc. Precis. Eng. 46 (1980) 1344-1350.

[114] Y. Inada, K. Syoji, T. Kuriyagawa, K. Unno, Development of wheel spindle for ultra-high speed surface grinding machine-studies of ultra-high speed grinding (1st Rep), J. Jpn. Soc. Precis. Eng. 62 (4) (1996) 569-573.

[115] M.J. Jackson, N. Barlow, B. Mills, W.B. Rowe, Mechanical design safety of vitreous bonded cylindrical grinding wheels, Br. Ceramic Trans. 94 (6) (1995) 221 229.

[116] S. Kawamura, et al., Deformation of the corner shapes in the grinding operation-model for calculating the stress distribution near work end and results, J. Jpn. Soc. Precis. Eng. 54 (1988) 1987-1992.

[117] K. Kounosu, Analysis of intermittent grinding phenomenon in cylindrical traverse grinding, J. Jpn. Soc. Precis. Eng. 53 (1987) 257-262.

[118] J.R. Murthy, G.C. Reddy, Floating hinge in machine tool structures - finite element representation, Comput.-Aided Des. 15 (1983) 201-208.

[119] M.I.M. Negm, M.M. Sadek, S.A. Tobias, Finite element prediction of compliances of grinding machine structures and their measured correlation, Int. J. Mach. 20 (1) (1980) 9-24.

[120] M.I.M. Negm, M.M. Sadek, S.A. Tobias, Finite element prediction of compliances of grinding machine structures and their measured correlation, in: 20th International MTDR Conference, 1979.

[121] T. Nishihara, S. Okuyama, S. Kawamura, Study on the geometrical accuracy in surface grinding. Process of forming the workpiece shape in plunge grinding, $\mathrm{J}$. Jpn. Soc. Precis. Eng. 57 (9) (1991) 1597-1602.

[122] T. Nishihara, S. Okuyama, S. Kawamura, S. Hanasaki, Study on the geometrical accuracy in surface grinding - thermal deformation on workpiece in transverse grinding, J. Jpn. Soc. Precis. Eng. 59 (7) (1993) $1145-1150$.

[123] S. Ohishi, Y. Furukawa, Analysis of workpiece temperature and grinding burn in creep feed grinding, Bull. JSME 28 (1985) 1775-1781.

[124] S. Ohishi, Y. Furukawa, Accuracy of work-pieces produced by one-pass creep feed grinding, Precis. Eng. 8 (3) (1986) 144-150.

[125] S. Ohishi, et al., Machining accuracy in creep feed grinding, J. Jpn. Soc. Precis. Eng. 51 (1985) 408-414. [126] S. Okuyama, Y. Nakamura, S. Kawamura, Study on the flatness of work produced by surface grinding effects of bending caused by grinding heat, J. Jpn. Soc. Precis. Eng. 54 (1988) 1496-1501.

[127] S. Okuyama, Y. Nakamura, S. Kawamura, Computation of grinding temperature considering the convective heat transfer, J. Jpn. Soc. Precis. Eng. 59 (4) (1993) 631-636.

[128] S. Okuyama, T. Nishihara, S. Kawamura, Study on the workpiece thermal deformation under wet grinding, in: Winter Ann. Meet., New Orleans, ASME, PED 64 (1993) 431-436.

[129] S. Okuyama, T. Nishihara, S. Kawamura, Study of the geometrical accuracy in surface grinding: thermal deformation of workpiece in transverse grinding, Int. J. Jpn. Soc. Prec. Eng. 28 (4) (1994) 305-310.

[130] B. Prasad, R.T. Haftka, M.S. Bao, Optimum design of an abrasive disk, J. Mech. Design, ASME 103 (4) (1981) 818-822.

[131] G.V. Rao, H. Chandrasekharan, Fracture behaviour of high-speed grinding wheels, in: G.C. Sih, et al. (Eds.), Fract. Mech. Eng. Appl., Sijthoff, 1979, pp. 493-503.

[132] V.G. Sharrock, J.C. Coetzee, Fatigue cracks in grinding mills, Forensic Eng. 3 (1) (1991) 55-62.

[133] H. Shibahara, T. Matsuo, S. Satonaka, Curvature of thin workpiece in surface grinding with superabrasive wheels (3rd Rep.-Influence of temperature distribution and transformation), J. Jpn. Soc. Precis. Eng. 59 (8) (1993) 1295-1300.

[134] W.M. Szydlowski, W.N. Weins, S.K. Gumate, A. Dhir, Evaluation of residual stresses in axisymmetric bodies from post-grinding deformation by finite element method, in: Aerotech '92, Anaheim, SAE, 1992, pp. 1-9.

[135] Y. Tani, Y. Hatamura, T. Nagao, A study on the dynamometer using the structure of parallel beams for grinding - analysis of the structure and the linearity of the dynamometer, J. Jpn. Soc. Precis. Eng. 48 (1982) $772-777$.

[136] Y. Tani, Y. Hatamura, T. Nagao, A study on the dynamometer using the structure of parallel beams for grinding, J. Jpn. Soc. Precis. Eng. 50 (1984) 875-879. [137] H.K. Tonshoff, et al., Messung und Berechnung mechanischer und thermischer Werkstoffbeanspruchun- 
gen beim Schleifen, in: Jahrbuch Schleifen, Honen, Lappen, 1985, pp. 31-47.

[138] H.K. Tonshoff, et al., Abrasives and their influence on forces, temperatures, and surface, in: 15th NAMRC, Lehigh University, Bethlehem, PA, vol. 2, 1987, pp. 70-89.

[139] A. Turbat, F. Convert, N. Skalli, Prediction of thermal residual stresses by the finite element method-effect of a phase change, in: R.W. Lewis (Ed.), Num. Meth. Thermal Prob., Pineridge Press, 1983, pp. 292-301.

[140] Z. Weizhong, The dynamic optimum design for the wheel head of a cylindrical grinding machine, in: Second International Modal Anal. Conf., Orlando, Union College, 1984, pp. 254-258.

[141] J. Yamakawa, et al., Deformation of the corner shapes in the grinding operation - formation mechanism of entrance burr, J. Jpn. Soc. Precis. Eng. 55 (1989) 685-690.

[142] J. Yamakawa, S. Kawamura, S. Okuyama, Effect of plastic zone near workpiece ends on grinding burrs. Model for calculating the stress distribution near work end and results, Bull. Jpn. Soc. Precis. Eng. 23 (3) (1989) 224-229.

[143] A. Yamamoto, Y. Moriguchi, Effect of clamping pressure on bursting speed of grinding wheel, J. Jpn. Soc. Precis. Eng. 48 (1982) 1039-1044.

[144] Z.K. Yao, Y.Y. Li, Thermomechanical model of 2D internal and external cylindrical grinding, Trans. North Am. Manuf. Res. Inst., SME 22 (1994) 127-134. [145] K. Yokoyama, R. Ichimiya, Analyses of thermal deformation of workpiece in honing process - numerical analyses of cylindrical and non-cylindrical workpieces, J. Jpn. Soc. Precis. Eng. 48 (1982) 919-924.

[146] K. Yokoyama, R. Ichimiya, FEM temperature analysis of workpiece with shape change, JSME Int. J., Ser I 34 (1) (1991) 30-36.

[147] T. Yoneda, I. Suzuki, Development of high-accuracy crankpin grinder using a servo synchrodrive work spindles, J. Jpn. Soc. Precis. Eng. 57 (6) (1991) 993998.

[148] L. Zhang, M. Mahdi, Applied mechanics in grinding - IV: Mechanism of grinding induced phase transformation, Int. J. Mach. Tools Manuf. 35 (10) (1995) 1397-1409.

\section{A.2.6. Broaching}

[149] V. Karri, Forces, power, stress and displacements in orthogonal keyway broaching operation, in: Intelligent Manuf. Syst., Vienna, Austria, 1994, pp. 443-448. [150] L. Vijayaraghavan, R. Krishnamurthy, H. Chandrasekaran, Evaluation of stress and displacement of tool and workpiece on broaching, Int. J. Mach. Tool Des. 21 (3/4) (1981) 263-270.

\section{A.2.7. Advanced machining}

[151] M. Alavi, T. Fabula, A. Schumacher, H.J. Wagner, Monolithic microbridges in silicon using laser machining and anisotropic etching, Sens. Actuators A 37/38 (1993) 661-665.

[152] S.G. Amin, M.H.M. Ahmed, H.A. Youssef, Computer-aided design of acoustic horns for ultrasonic machining using finite element analysis, J. Mater. Process. Technol. 55 (3/4) (1995) 254-260.

[153] C.A. Anderson, R.R. Stevens, R.L. Rhorer, Numerical analysis of deformation and surface generation in ultraprecision machining, in: Num. Implem. Appl. Constit. Models FEM, AMD 213, ASME (1995) 115124.

[154] H. Baltes, et al., IMEMS - integrated micro electro mechanical systems by VLSI and micromachining, in: Proceedings of the ESSDERC, Edinburgh, UK, 1994, pp. 273-280.

[155] D.S. Brookes, Computer-aided shape prediction of electrochemically machined work using the method of finite elements, $\mathrm{PhD}$ Thesis, University of Manchester, UK, 1984.

[156] G.H. Burdorf, Stationary electrochemical machining of long, narrow, high-precision grooves, $\mathrm{PhD}$ Thesis, University of California, Los Angeles, 1993.

[157] R. Butt, Optimum design with finite elements: design of electrochemical machining, J. Comput. Appl. Math. 47 (2) (1993) 151-165.

[158] C.C. Chen, W. Cheng, Material properties and laser cutting of composites, SAMPE Tech. Conf. 23 (1991) 274-287.

[159] G. Coffignal, M. Touratier, A computer-aided design program for the tuning of ultrasonic machining tools using the finite-element method, in: D.J. DeMichele (Ed.), Fifth International Modal Anal. Conference, Union College, 1987, pp. 1438-1444.

[160] J.N. Dekker, M.H. Zonneveld, Thermal severing. The cutting of brittle materials by thermally induced fracture, in: K. Salama, (Ed.), Adv. Fract. Res., vol. 4, Pergamon, Oxford, 1989, pp. 2825-2834.

[161] B. Diem, et al., SOI SIMOX; From bulk to surface micromachining, a new age for silicon sensors and actuators, Sens. Actuators A 46 (1/3) (1995) 8-16. [162] C.M. Elliott, On a variational inequality formulation of an electrochemical machining moving boundary problem and its approximation by the finite element method, J. Inst. Math. Appl. 25 (2) (1980) 121-131. [163] R. Fortunier, L. Coudreuse, Prediction of microstructure and internal stresses due to laser cutting and welding of thin plates, Bull. Cercle Etud. Metaux 16 (7) (1993) 27.1-5.

[164] K. Furutani, N. Mohri, T. Higuchi, Direct drive mechanism of EDM electrode utilizing elliptical movement, J. Jpn. Soc. Precis. Eng. 61 (5) (1995) 672-676. 
[165] H. Gan, P.L. Levin, C.A. Brown, Modelling and analysis of the electric field for a canonical problem in EDM, COMPEL 12 (1) (1993) 1-19.

[166] S. Hanasaki, M. Touge, E. Tanokubo, Y. Hasegawa, In situ observation of micro-cutting of $\mathrm{Al}-$ Si alloy by using scanning electron microscope, J. Jpn. Inst. Light Met. 39 (10) (1989) 705-709.

[167] S. Hanasaki, J. Fujiwara, T. Miyamoto, Measurement of strain rate near cutting edge by image processing on micro-cutting commercially pure aluminum in SEM, J. Jpn. Inst. Light Met. 46 (4) (1996) 177-182. [168] H. Hardisty, A.R. Mileham, H. Shirvarni, Finite element simulation of the electrochemical machining process, Ann. CIRP 42 (1) (1993) 201-204.

[169] H. Hardisty, A.R. Mileham, H. Shirvarni, Analysis and computer simulation of the electrochemical machining process: a stepped moving tool eroding a plane surface, Proc. Inst. Mech. Eng., Part B 210 (2) (1996) 109-118.

[170] R.M., Hilbinger, S. Mayer, C. Koerner, H.W. Bergmann, Eigenspannungen beim Laserstrahlschweissen verschiedener Baustaehle, Haerterei-Tech. Mitteil. 50 (6) (1995) 380-388.

[171] L.W. Hourng, C.S. Chang, Numerical simulation of electrochemical drilling, J. Appl. Electrochem. 23 (4) (1993) 316-321.

[172] L.W. Hourng, C.C. Chen, Numerical simulation and analysis of the electrochemical machining, J. Chin. Soc. Mech. Eng. 13 (1) (1992) 52-61.

[173] T. Inamura, N. Takezawa, Computer simulation of nanoscale cutting, J. Jpn. Soc. Precis. Eng. 58 (7) (1992) 1125-1128.

[174] T. Inamura, N. Takezawa, Y. Kumaki, Mechanics of energy dissipation in nanoscale cutting, Ann. CIRP 42 (1) (1993) 79-82.

[175] T. Inamura, N. Takezawa, Y. Kumaki, Atomic/ continuum model transformation and its application to stress-strain analysis of nanoscale cutting, J. Jpn. Soc. Precis. Eng. 60 (4) (1994) 570-575.

[176] M. Ishiyama, et al., FEM simulation of gas and plasma cutting with emphasis on precision of cutting, Trans. JWRI 23 (1) (1994) 93-102.

[177] V.K. Jain, P.C. Pandey, Finite element approach to the two-dimensional analysis of electrochemical machining, Precis. Eng. 2 (1) (1980) 23-28.

[178] V.K. Jain, P.C. Pandey, Application of finite elements technique for analysis of electro-chemical wire cutting process, J. Inst. Eng. (India) Mech. Eng. Div. 60 (ME6) (1980) 203-210.

[179] V.K. Jain, P.C. Pandey, Tooling design for ECM - a finite element approach, J. Eng. Ind., ASME 103 (2) (1981) 183-191.

[180] V.K. Jain, P.G. Yogindra, S. Murugan, Prediction of anode profile in ECBD and ECD operations, Int. J. Machine Tools Manuf. 27 (1) (1987) 113-134.
[181] M.J. Kim, P. Majumdar, Computational model for high-energy laser-cutting process, Numer. Heat Transf. A 27 (6) (1995) 717-733.

[182] M.J. Kim, Z.H. Chen, P. Majumdar, A finite element model for material removal using high energy laser, in: B. Singh (Ed.), Comp. Model. Simul. Manuf. Proc., MD20, ASME, 1990, pp. 313-320.

[183] M.J. Kim, Z.H. Chen, P. Majumdar, Finite element modelling of the laser cutting process, Comput. Struct. 49 (2) (1993) 231-241.

[184] J.F. Li, N. Nishio, A. Kawasaki, R. Watanabe, Development of diamond tools for superprecision machining with compositionally graded layers from silicon carbide shank of diamond chip, J. Jpn. Soc. Powder Powder Metall. 41 (6) (1994) 653-657.

[185] L.E. Lindgren, A. Carlestam, An improved twodimensional model of flame-cutting, in: Int. Conf. Computer-Assisted Mater. Design, Tokyo, 1993, pp. $141-146$.

[186] L.E. Lindgren, A. Carlestam, M. Jonsson, Computational model of flame-cutting, J. Eng. Mater. Technol., ASME 115 (4) (1993) 440-445.

[187] P. Madhu, V.K. Jain, T. Sundararajan, K.P. Rajurkar, Finite element analysis of EDM process, Process. Adv. Mat. 1 (3/4) (1991) 161-173.

[188] K. Maekawa, T. Kitagawa, A. Kubo, Plasma hot machining for difficult-to-cut materials, 2nd RepSimulation analysis of cutting mechanism of high manganese steels, J. Jpn. Soc. Precis. Eng. 54 (1988) 567-573.

[189] P. Majumdar, Z.H. Chen, M.J. Kim, Evaporative material removal process with a continuous wave laser, Comput. Struct. 57 (4) (1995) 663-671.

[190] A.R. Mileham, et al., Electrochemical machining using computer simulation, in: Tenth ISPE/IFAC International Conference CAD/CAM, Robot. Factories Future, Ottawa, Canada, 1994, pp. 81-86.

[191] S. Motonishi, Y. Hara, K. Yoshida, New micro cutting system with high resolution, J. Jpn. Soc. Precis. Eng. 57 (12) (1991) 2139-2144.

[192] H.A. Nied, E.M. Perry, Finite element simulation of the electrochemical machining process, in: B. Singh (Ed.), Comput. Model. Simul. Manuf. Proc., MD 20, ASME, 1990, pp. 37-57.

[193] K. Przyklenk, M. Schlatter, Simulation of the cutting operation for high-pressure water jet cutting, Werkstattstechnik 76 (12) (1986) 715-719.

[194] N. Rajendran, An experimental and theoretical study of heat transfer effects during a laser-cutting process, PhD Thesis, Iowa State University, 1990.

[195] K. Ravindran, J. Srinivasan, A.G. Marathe, Finite element solution of surface-tension driven flows in laser surface melting, Mech. Res. Commun. 22 (3) (1995) 297-304.

[196] K. Sawada, K. Imai, Y. Takeuchi, T. Sata, Development of ultraprecision machining center with closed- 
loop structure and its control, Ann. CIRP 44 (1) (1995) 369-372.

[197] K. Sawada, K. Imai, Y. Takeuchi, T. Sata, Development of ultraprecision machining center with closedloop structure and its control, Trans. Jpn. Soc. Mech. Eng., Ser C 61 (585) (1995) 2121-2127.

[198] K.H.W. Seah, Y.S. Wong, L.C. Lee, Design of tool holders for ultrasonic machining using FEM, J. Mater. Process. Technol. 37 (1/4) (1993) 801-816.

[199] G. Spur, J. Schoenbeck, Anode erosion in wireEDM - a theoretical model, Ann. CIRP 42 (1) (1993) $253-256$.

[200] K. Ueda, T. Sugita, H. Hiraga, A J-integral approach to material removal mechanisms in microcutting of ceramics, Ann. CIRP 40 (1) (1991) 61-64.

[201] M.H.H. Van Dijk, B.T.M. Verhappen, J.K.M. Jansen, M.J. Noot, FEM model to support electro chemical drilling of turbulated cooling holes, in: International Gas Turbine Aeroengine Congress Exp., Hague, ASME, 1994, pp. 1-6.

[202] Y.S. Wong, et al., Approximation of exponential curves for CNC machining of toolholders used in ultrasonic machining, J. Mater. Process. Technol. 48 (1/4) (1995) 713-719.

[203] T.M. Yue, T.W. Chan, H.C. Man, W.S. Lau, Analysis of ultrasonic-aided laser drilling using finite element method, Ann. CIRP 45 (1996) 169-172.

[204] Y. Zhou, J.J. Derby, Cathode design problem in electrochemical machining, Chem. Eng. Sci. 50 (17) (1995) 2679-2689.

[205] D. Zhu, C.Y. Yu, Investigation on the design of tool shape in ECM, in: Winter Ann. Meet., Anaheim, PED 58, ASME (1992) 181-190.

\section{A.3. Effects of geometric and process parameters}

[1] N. Arai, et al., A study on the cutting of quenched steel by tool having negative rake angle, Sci. Eng. Rev. Doshisha Univ. 33 (3) (1992) 185-198.

[2] W.C. Chen, Effect of the cross-sectional shape design of a drill body on drill temperature distributions, Int. Commun. Heat Mass Transf. 23 (3) (1996) 355366.

[3] W.C. Chen, et al., Twist drills with special profiles, Zeitschr. Wirtsch. Fabrikbetr. 90 (5) (1995) 226-228. [4] K.F. Eldridge, et al., Thermoviscoplastic finite element modeling of machining under various cutting conditions, in: Nineteenth Conference North American Manuf. Research Institute, SME, 1991, pp. 162-170. [5] V.K. Jain, P.G. Yogindra, S. Murugan, Prediction of anode profile in ECBD and ECD operations, Int. J. Mach. Tools Manuf. 27 (1) (1987) 113-134.

[6] N.N. Kakade, J.G. Chow, Finite element analysis of engine bore distortions during boring operation, J. Eng. Ind., ASME 115 (4) (1993) 379-384.
[7] C.R. Liu, Z.C. Lin, Effects of shear plane boundary condition on stress loading in orthogonal machining, Int. J. Mech. Sci. 27 (1985) 281-290.

[8] K. Maekawa, H. Ohhata, Simulation analysis of three-dimensional continuous chip formation processes (3rd Rep-Effects of tool geometry on chip flow and wear), J. Jpn. Soc. Precis. Eng. 62 (4) (1996) 535-539. [9] P.D. Muraka, G. Barrow, S. Hinduja, Influence of the process variables on the temperature distribution in orthogonal machining using the finite element method, Int. J. Mech. Sci. 21 (1979) 445-456.

[10] R. Murthy, et al., Optimisation of functional properties of machine tool structures - a finite element analysis, in: Proceedings of the Twentieth International MTDR Conference, 1979.

[11] S. Nakamura, A. Yamamoto, Study on wide variation of tool life owing to engagement angle, Bull. Jpn. Soc. Precis. Eng. 16 (4) (1982) 231-236.

[12] S. Nakamura, et al., Fluctuation of stresses upon rake surface for various engagement angle - study of biting mechanism in interrupted cutting, J. Jpn. Soc. Precis. Eng. 47 (1981) 962-968.

[13] T. Nishihara, S. Okuyama, S. Kawamura, Study on the geometrical accuracy in surface grinding. Process of forming the workpiece shape in plunge grinding, $\mathrm{J}$. Jpn. Soc. Precis. Eng. 57 (9) (1991) 1597-1602.

[14] T. Nishihara, S. Okuyama, S. Kawamura, S., Hanasaki, Study on the geometrical accuracy in surface grinding - thermal deformation on workpiece in transverse grinding, J. Jpn. Soc. Precis. Eng. 59 (7) (1993) $1145-1150$.

[15] T.D. Sachdeva, Finite element analysis of elastic contact problem and its application for the study of the effect of joint flexibility of the free vibration characteristics, PhD Thesis, IIT Delhi, India, 1979.

[16] T.D. Sachdeva, C.V. Ramakrishnan, The effect of interface friction on the inplane flexibilities of machine tool joints, Int. J. Mech. Sci. 23 (1981) 149-159.

[17] H. Schulz, M. Kaufeld, Computer simulation for adapting the metal-cutting parameters to manufacturing accuracy, Werkstatt Betr. 119 (12) (1986) 10091012.

[18] S.V.M. Selvam, C. Sujatha, Twist drill deformation and optimum drill geometry, Comput. Struct. 57 (5) (1995) 903-914.

[19] H. Shibahara, T. Matsuo, S. Satonaka, Curvature of thin workpiece in surface grinding with superabrasive wheels (3rd Rep-Influence of temperature distribution and transformation), J. Jpn. Soc. Precis. Eng. 59 (8) (1993) 1295-1300.

[20] A.J. Shih, Finite element analysis of the rake angle effect in orthogonal metal cutting, in: Winter Ann. Meet., New Orleans, PED 64, ASME (1993) 475-483. [21] A.J. Shih, Finite element analysis of the rake angle effects in orthogonal metal cutting, Int. J. Mech. Sci. 38 (1) (1996) 1-17. 
[22] K. Shintani, et al., Effect of CBN cutting tool geometry on intermittent cutting of hardened steel, J. Jpn. Soc. Precis. Eng. 50 (1984) 1950-1955.

[23] U.P. Singh, W. Klingenberg, W. Urquhart, Effect of tool geometry on punching performance, J. Eng. Ind., ASME 116 (4) (1994) 508-513.

[24] O. Tekinalp, A.G. Ulsoy, Effects of geometric and process parameters on drill transverse vibrations, in: Winter Ann. Meet., Chicago, PED 33, ASME (1988) $33-40$.

[25] O. Tekinalp, A.G. Ulsoy, Effects of geometric and process parameters on drill transverse vibrations, J. Eng. Ind., ASME 112 (2) (1990) 189-194.

[26] Z. Wen, et al., Structural parameter identification of machine tool spindle supports by complex condensation method, in: 6th Int. Modal Anal. Conf., Kissimmee, 2, SEM, (1988) 1283-1287.

[27] A. Yamamoto, Y. Moriguchi, Effect of clamping pressure on bursting speed of grinding wheel, J. Jpn.

Soc. Precis. Eng. 48 (1982) 1039-1044.

[28] J.X. Yuan, Identification of the machine tool structural parameters by dynamic data system (DDS) and finite element method, PhD Thesis, University of Wisconsin, Madison, 1983.

[29] J.X. Yuan, X.M. Wu, Identification of the joint structural parameters of machine tool by DDS and FEM, J. Eng. Ind., ASME 107 (1985) 64-69.

\section{A.4. Thermal aspects in machining}

[1] A. Abdel-Hamid, A.S. Wifi, M. El Gallab, A three dimensional finite element thermomechanical analysis of intermittent cutting process, J. Mater. Process. Technol. 56 (1/4) (1996) 643-654.

[2] G.K. Adil, V.K. Jain, T. Sundararajan, Finite element analysis of temperature in accelerated cutting, Int. J. Mach. Tool Manuf. 28 (1988) 577-590.

[3] J.S. Agapiou, M.F. De Vries, On the determination of thermal phenomena during drilling. I-Analytical models of twist drill temperature distributions, Int. J. Mach. Tools Manuf. 30 (2) (1990) 203-215.

[4] N. Arai, et al., Study on low frequency vibratory drilling of SUS304 (Cutting temperature of drill point), Trans. Jpn. Soc. Mech. Eng., Ser C 56 (527) (1990) 1960-1964.

[5] M.H. Attia, L. Kops, Importance of contact pressure distribution on heat transfer in structural joints of machine tools, J. Eng. Ind., ASME 102 (2) (1980) 159-167.

[6] M.H. Attia, L. Kops, A method for generating desired contact pressure distributions in experimental interfacial studies, J. Eng. Ind., ASME 107 (1985) 241-246.

[7] W. Bouzid, J.L. Lebrun, A numerical method to determine temperature distribution in orthogonal ma- chining, in: J.L. Chenot (Ed.), Num. Meth. Ind. Form. Process., Balkema, Rotterdam, 1992, pp. 895-900.

[8] J.F.L. Chan, P.M. Braiden, The calculation of stresses in cutting tools, in: Appl. Solid Mech., Elsevier, Amsterdam, 1986, pp. 245-254.

[9] W.C. Chen, Effect of the cross-sectional shape design of a drill body on drill temperature distributions, Int. Commun. Heat Mass Transf. 23 (3) (1996) 355366.

[10] T.H.C. Childs, K. Maekawa, P. Maulik, Effects of coolant on temperature distribution in metal machining, Mater. Sci. Tech. 4 (11) (1988) 1006-1019.

[11] J.G.C. Chow, Sensor development for on-line monitoring and the determination of temperature distributions in machining, $\mathrm{PhD}$ Thesis, Carnegie-Mellon University, 1984.

[12] S. Darwish, R. Davies, Investigation of the heat flow through bonded and brazed metal cutting tools, Int. J. Mach. Tools Manuf. 29 (2) (1989) 229-237.

[13] M.D. Diehl, D.R. Durham, Modeling of thermal behavior for diamond coated alumina tool inserts, in: NAMRC XXII Conf., Evanston, 1994, pp. 143/1-6. [14] M.O. Duffy, Heat transfer analysis of the grinding process, PhD Thesis, The University of Connecticut, 1992.

[15] T.I. El-Wardany, E. Mohammed, M.A. Elbestawi, Cutting temperature of ceramic tools in high speed machining of difficult to cut materials, Int. J. Mach. Tools Manuf. 36 (5) (1996) 611-634.

[16] K.F. Eldridge, et al., Thermoviscoplastic finite element modeling of machining under various cutting conditions, in: Nineteenth Conference North American Manuf. Res. Inst. SME, 1991, pp. 162-170.

[17] L. Fourment, et al., Incremental mass conservation and adaptive remeshing for the thermo-mechanical coupling between workpiece and tool in non steady metal forming, in: S.F. Shen, P. Dawson (Eds.), NUMIFORM 95, Balkema, Rotterdam, 1995, pp. 431434.

[18] S. Fraser, M.H. Attia, M.O.M. Osman, Modelling, identification and control of thermal deformation of machine tool structures: Part I-Concept of generalized modelling, 1994 Int. Mech. Eng. Cong. Expo. PED 68, ASME (1994) 931-944.

[19] S. Fraser, M.H. Attia, M.O.M. Osman, Modelling, identification and control of thermal deformation of machine tool structures: Part II - Generalized transfer functions, 1994 Int. Mech. Eng. Cong. Expo. PED 68, ASME (1994) 945-953.

[20] K.H. Fuh, J.S. Huang, Thermal analysis of creepfeed grinding, J. Mater. Process. Technol. 43 (2/4) (1994) 109-124.

[21] K.H. Fuh, W.C. Chen, Temperature rise in twist drills with a finite element approach, Int. Commun. Heat Mass Transf. 21 (3) (1994) 345-358. 
[22] T. Ihara, et al., Analytical prediction of cutting edge chipping in interrupted turning operation - transient distributions of temperature and thermal stress, J. Jpn. Soc. Precis. Eng. 48 (1982) 757-763.

[23] T. Inamura, et al., Improvement of a thermal simulation model based on experimental data, J. Jpn. Soc. Precis. Eng. 54 (1988) 1907-1914.

[24] J. Jedrzejewski, W. Modrzycki, A new approach to modeling thermal behavior of a machine tool under service conditions, Ann. CIRP 41 (1) (1992) 455-458. [25] T. Kagiwada, T. Kanauchi, Numerical analyses of cutting temperatures and flowing ratios of generated heat, JSME Int. J., Ser III 31 (1988) 624-633.

[26] Y. Kakino, et al., A study on the generation of thermal crack of cutting tool, J. Jpn. Soc. Precis. Eng. 51 (1985) 1705-1710.

[27] K.W. Kim, H.C. Sin, Development of a thermoviscoplastic cutting model using finite element method, Int. J. Mach. Tools Manuf. 36 (3) (1996) 379-398.

[28] Y. Kobayashi, T. Watanabe, Y. Yoshida, Effects of heat fluxes from environment on the temperature distribution of elements of a machine tool, Trans. Jpn. Soc. Mech. Eng., Ser C 57 (541) (1991) 3045-3049.

[29] N. Koreta, K. Watabe, R. Hashimoto, K. Mizuta, Study on control of thermal deformation of machine tool structure due to room temperature's change by use of thermal insulating balancing boards, J. Jpn. Soc. Precis. Eng. 60 (6) (1994) 853-857.

[30] N. Koreta, et al., Thermoelectric cooling of machine tool spindle, J. Jpn. Soc. Precis. Eng. 60 (5) (1994) 652-656.

[31] S. Lee, H. Shinno, C. Inaba, Y. Ito, New simulation method for thermal-appropriate design of machine tool structure (its application to clarify effects of main bearing), Trans. Jpn. Soc. Mech. Eng., Ser C 57 (538) (1991) 2092-2099.

[32] X. Li, A computer-based numerical study of the role of cooling in machining, $\mathrm{PhD}$ Thesis, University of New South Wales, Australia, 1992.

[33] X. Li, Effect of coolant flow rate on cooling in machining, in: NAMRC XXIII Conf., Houghton, 1995, pp. $1-6$.

[34] X. Li, E.M. Kopalinsky, P.L.B. Oxley, Numerical method for determining temperature distribution in machining with coolant-Part 1: Modelling the process, Proc. Inst. Mech. Eng. B 209 (B1) (1995) 33-43. [35] X. Li, E.M. Kopalinsky, P.L.B. Oxley, Numerical method for determining temperature distribution in machining with coolant-Part 2: Calculation method and results, Proc. Inst. Mech. Eng. B 209 (B1) (1995) $45-52$.

[36] J. Lin, Inverse estimation of the tool-work interface temperature in end milling, Int. J. Mach. Tools Manuf. 35 (5) (1995) 751-760.

[37] J. Lin, S.L. Lee, C.I. Weng, Estimation of cutting temperature in high speed machining, J. Eng. Ind., ASME 114 (3) (1992) 289-296.
[38] Z.C. Lin, S.Y. Lin, A coupled finite element model of thermo-elastic-plastic large deformation for orthogonal cutting, J. Eng. Mater. Technol., ASME 114 (2) (1992) 218-226.

[39] Z.C. Lin, W.C. Pan, A thermo-elastic-plastic model with special elements in a cutting process with tool flank wear, Int. J. Mach. Tools Manuf. 34 (6) (1994) 757-770.

[40] Z.C. Lin, F.S. Chang, Y.T. Lin, The effect of tool flank wear on the temperature distribution of a machined workpiece, J. Chin. Inst. Eng. 10 (4) (1987) $353-362$.

[41] Z.C. Lin, Y.Y. Lin, C.R. Liu, Effect of thermal load and mechanical load on the residual stress of a machined workpiece, Int. J. Mech. Sci. 33 (4) (1991) $263-278$.

[42] C.H.H. Lo, Real-time error compensation on machine tool through optimal thermal error modeling, PhD Thesis, The University of Michigan, 1994.

[43] S. Lo Casto, et al., Measurement of temperature distribution within tool in metal cutting. Experimental tests and numerical analysis, J. Mech. Work. Technol. 20 (1989) 35-46.

[44] S. Lo Casto, et al., Cutting temperatures evaluation in ceramic tools: experimental tests, numerical analysis and SEM observations, Ann. CIRP 43 (1) (1994) 7376.

[45] S. Lo Casto, E. Lo Valvo, M. Piacentini, V.F. Ruisi, Method to evaluate cutting temperature distribution within ceramic tools, Metall. Ital. 85 (12) (1993) 751-755.

[46] K. Maekawa, T.H.C. Childs, Thermal analysis of cutting tools in metal machining, in: Num. Meth. Therm. Prob. VII, Pineridge Press, 1991, pp. 12911301.

[47] K. Maekawa, I. Ohshima, Finite element simulation systems for metal machining II-Thermal analysis of cutting tools, J. Fac. Eng. Ibaraki Univ. (39) (1991) $67-76$.

[48] K. Maekawa, I. Ohshima, R. Murata, Finite element analysis of temperature and stresses within an internally cooled cutting tool, Bull. Jpn. Soc. Precis. Eng. 23 (3) (1989) 243-246.

[49] K. Maekawa, I. Ohshima, R. Murata, Thermal analysis of internally cooled cutting tools, J. Jpn. Soc. Precis. Eng. 57 (11) (1991) 2011-2016.

[50] K. Maekawa, I. Ohshima, A. Kubo, T. Kitagawa, Improvements in cutting efficiency of Ti-6Al-6V-2Sn titanium alloy (2nd Report-Investigations for reducing tool tip temperature), J. Jpn. Soc. Precis. Eng. 59 (6) (1993) 927-932.

[51] K. Maekawa, Y. Nakano, T. Kitagawa, Finite element analysis of thermal behavior in metal machining (1st Rep, Influence of thermal properties on cutting temperature), Trans. Jpn. Soc. Mech. Eng., Ser C 62 (596) (1996) 1587-1593. 
[52] K. Maekawa, Y. Nakano, T. Kitagawa, Finite element analysis of thermal behavior in metal machining (2nd Rep, Determination of energy balance and its application to 3D analysis), Trans. Jpn. Soc. Mech. Eng., Ser C 62 (596) (1996) 1594-1599.

[53] M. Mahdi, L. Zhang, The finite element thermal analysis of grinding processes by ADINA, Comput. Struct. 56 (2/3) (1995) 313-320.

[54] M. Matsuo, T. Yasui, T. Inamura, M. Matsumura, A high-speed test of thermal effect for a machine-tool structure based on modal analysis, J. Jpn. Soc. Precis. Eng. 50 (1984) 1413-1418.

[55] M. Matsuo, et al., Measurement and decomposition of thermal deformation of a machining center by using touch-probe and mathematical model, J. Jpn. Soc. Precis. Eng. 55 (9) (1989) 1681-1686.

[56] T. Moriwaki, C. Zhao, M. Nishiuchi, Thermal deformation of machining center due to temperature change in the environment, Trans. Jpn. Soc. Mech. Eng., Ser C 57 (539) (1991) 2447-2452.

[57] T. Moriwaki, N. Sugimura, S. Luan, Combined stress, material flow and heat analysis of orthogonal micromachining of copper, Ann. CIRP 42 (1) (1993) $75-78$.

[58] T. Moriwaki, et al., Development of modeling system for $\mathrm{CAD} / \mathrm{CAE}$ of machine tool: application of thermal analysis for moving parts, J. Jpn. Soc. Precis. Eng. 60 (7) (1994) 959-963.

[59] P.D. Muraka, G. Barrow, S. Hinduja, Influence of the process variables on the temperature distribution in orthogonal machining using the finite element method, Int. J. Mech. Sci. 21 (1979) 445-456.

[60] T. Nishihara, S. Okuyama, S. Kawamura, S. Hanasaki, Study on the geometrical accuracy in surface grinding - thermal deformation on workpiece in transverse grinding, J. Jpn. Soc. Precis. Eng. 59 (7) (1993) 1145-1150.

[61] S. Ohishi, Y. Furukawa, Analysis of workpiece temperature and grinding burn in creep feed grinding, Bull. JSME 28 (1985) 1775-1781.

[62] S. Ohishi, et al., Machining accuracy in creep feed grinding, J. Jpn. Soc. Precis. Eng. 51 (1985) 408-414. [63] S. Okuyama, et al., Study on the flatness of work produced by surface grinding-effects of bending caused by grinding heat, J. Jpn. Soc. Precis. Eng. 54 (1988) 1496-1501.

[64] S. Okuyama, Y. Nakamura, S. Kawamura, Computation of grinding temperature considering the convective heat transfer, J. Jpn. Soc. Precis. Eng. 59 (4) (1993) 631-636.

[65] S. Okuyama, T. Nishihara, S. Kawamura, Study on the workpiece thermal deformation under wet grinding, in: Winter Ann. Meet., New Orleans, PED 64, ASME (1993) 431-436.
[66] S. Okuyama, et al., Study of the geometrical accuracy in surface grinding: thermal deformation of workpiece in transverse grinding, Int. J. Jpn. Soc. Prec. Eng. 28 (4) (1994) 305-310.

[67] V. Prakash, Finite element method for temperature distribution in synthetic diamond cutters during orthogonal rock cutting, PhD Thesis, Kansas State University, 1986.

[68] R.C. Radulescu, A general cutting process model for high-speed machining: dynamic and thermal considerations, PhD Thesis, University of Illinois, Urbana, 1993.

[69] N. Rajendran, An experimental and theoretical study of heat transfer effects during a laser-cutting process, PhD Thesis, Iowa State University, 1990.

[70] R. Rakotomalala, P. Joyot, M. Touratier, Arbitrary Lagrangian-Eulerian thermomechanical finite-element model of material cutting, Commun. Num. Meth. Eng. 9 (12) (1993) 975-987.

[71] K. Ravindran, J. Srinivasan, A.G. Marathe, Finite element solution of surface-tension driven flows in laser surface melting, Mech. Res. Commun. 22 (3) (1995) 297-304.

[72] H. Sasahara, T. Obikawa, T. Shirakashi, Analytical prediction of the characteristics within machined surface layer (Part 3) - The thermal and mechanical effects on machined surface, J. Jpn. Soc. Precis. Eng. 60 (12) (1994) 1801-1805.

[73] H. Shibahara, T. Matsuo, S. Satonaka, Curvature of thin workpiece in surface grinding with superabrasive wheels (3rd Rep-Influence of temperature distribution and transformation), J. Jpn. Soc. Precis. Eng. 59 (8) (1993) 1295-1300.

[74] A.J.M. Shih, S. Chandrasekar, H.T.Y. Yang, Finite element simulation of metal cutting process with strain-rate and temperature effects, in: Winter Ann. Meet., Dallas, PED 43, ASME (1990) 11-24.

[75] M.G. Stevenson, P.K. Wright, J.G. Chow, Further developments in applying the finite element method to the calculation of temperature distributions in machining, J. Eng. Ind., ASME 105 (1983) 149-154.

[76] J.S. Strenkowski, M.H. Luh, Thermal analysis of orthogonal cutting using a thermo-viscoplastic finite element model, in: Winter Ann. Meet., San Francisco, HTD 123, ASME (1989) 249-258.

[77] J.S. Strenkowski, K.J. Moon, Finite element prediction of chip geometry and tool/workpiece temperature distributions in orthogonal metal cutting, J. Eng. Ind., ASME 112 (4) (1990) 313-318.

[78] G. Subramani, Modeling of the cylinder boring process for prediction of cutting force, temperature and surface error, $\mathrm{PhD}$ Thesis, University of Illinois, Urbana, 1991.

[79] T. Takase, R. Kurokawa, Y. Imai, Thermal stress cutting of cylindrical brittle materials, Trans. Jpn. Soc. Mech. Eng., Ser A 60 (570) (1994) 385-389. 
[80] A.A.O. Tay, Review of methods of calculating machining temperature, J. Mater. Process. Technol. 36 (3) (1993) 225-257.

[81] A.A.O. Tay, Importance of allowing for the variation of thermal properties in the numerical computation of temperature distribution in machining, J. Mater. Process. Technol. 28 (1/2) (1991) 49-58.

[82] T.C. Tszeng, W.T. Wu, J.P. Tang, Prediction of distortion during heat treating and machining processes, in: Sixteenth Conference Heat Treat., Cincinnati, ASM, 1996, pp. 9-15.

[83] S.S. Ukani, C.W. Chang, A.A. Shabana, Thermoelastic analysis of flexible multibody machine-tool mechanisms, J. Mech., Transm., Aut. Design, ASME 110 (1988) 48-55.

[84] A. Waked, R.K. Al-Abbas, M.M. Sadek, Thermal behaviour of bonded carbide tipped turning tool during cutting, Indian J. Technol. 29 (11) (1991) 513-518.

[85] A. Waked, R.K. Al-Abbas, M.M. Sadek, Thermal performance of the bonded carbide tipped tool as compared with commercially available tools, Proc. Inst. Mech. Eng., Part B 205 (1) (1991) 35-42.

[86] X. Wang, et al., Analysis and computation of temperature field and thermal deformation on the column of vertical lathe by finite element method, in: G. Yagawa, S.N. Atluri (Eds.), Comp. Mech., Springer, Berlin, 1986, pp. 8/109.

[87] Z.Y. Wang, C. Sahay, K.P. Rajurkar, Tool temperatures and crack development in milling cutters, Int. J. Mach. Tools Manuf. 36 (1) (1996) 129-140.

[88] C. Wiesner, Residual stresses after orthogonal machining of AISI 304: numerical calculation of the thermal component and comparison with experiments, Metall. Trans. A 23 (3) (1992) 989-996.

[89] H. Wu, J.E. Mayer, An analysis of thermal cracking of carbide tools in intermittent cutting, J. Eng. Ind., ASME 101 (2) (1979) 159-164.

[90] Z.K. Yao, Y.Y. Li, Thermomechanical model of 2D internal and external cylindrical grinding, Trans. North Am. Manuf. Res. Inst. 22, SME (1994) 127-134. [91] K. Yokoyama, R. Ichimiya, Analyses of thermal deformation of workpiece in honing process - numerical analyses of cylindrical and non-cylindrical workpieces, J. Jpn. Soc. Precis. Eng. 48 (1982) 919-924.

[92] K. Yokoyama, R. Ichimiya, FEM temperature analysis of workpiece with shape change (shortening of CPU time by calculation involving nodes movement), Trans. Jpn. Soc. Mech. Eng., Ser C 56 (524) (1990) 1034-1040.

[93] K. Yokoyama, R. Ichimiya, FEM temperature analysis of workpiece with shape change, JSME Int. J., Ser I 34 (1) (1991) 30-36.

[94] M.A. Younis, Mechanical and thermal stresses in clamped, brazed, and bonded carbide tools, J. Eng. Ind., ASME 114 (4) (1992) 377-385.

\section{A.5. Residual stresses in machining}

[1] W. Arnold, et al., Numerical determination of the residual stress in machined surfaces, Wiss. Z. Tech. Hochsch. Karl-Marx-Stadt 27 (5) (1985) 768-772.

[2] M. Beghini, L. Bertini, P. Raffaelli, Numerical analysis of plasticity effects in the hole-drilling residual stress measurement, J. Test Eval. 22 (6) (1994) $522-$ 529.

[3] J.M. Boag, M.T. Flaman, J.A. Herring, Considerations of using the hole drilling method for measuring residual stresses in engineering components, in: W.B. Young (Ed.), Resid. Str. Design Proc. Mat. Select., ASM, 1987, pp. 1-9.

[4] H. Eda, K. Kishi, Simulation analysis of residual stress distribution in metal grinding, Werkstatt. Betr. 119 (12) (1986) 1019-1024.

[5] H. Eda, et al., Simulation analysis of residual stress in ground surface layer by use of FEM, J. Jpn. Soc. Precision Eng. 47 (1981) 314-319.

[6] G. Feng, Surface grinding induced phase transformation and residual stresses in $\mathrm{Al}_{2} \mathrm{O}_{3}-\mathrm{ZrO}_{2}$ composites, $\mathrm{PhD}$ Thesis, Rutgers State University of New Jersey, 1993.

[7] R.M. Hilbinger, S. Mayer, C. Koerner, H.W. Bergmann, Eigenspannungen beim Laserstrahlschweissen verschiedener Baustaehle, Haerterei-Tech. Mitteil. 50 (6) (1995) 380-388.

[8] K. Honda, T. Torii, Z. Fei, Analysis and measurements of residual-stress redistribution due to material removal in a plate, J. Soc. Mater. Sci. Jpn. 37 (415) (1988) 391-397.

[9] K. Honda, T. Torii, Z. Fei, Residual-stress redistribution and deformation due to material removal during the formation of a full-depth hole in a plate, Trans. Jpn. Soc. Mech. Eng. 55 (512A) (1989) 879-887.

[10] K. Honda, T. Torii, Z. Fei, Analysis and measurements of residual stress redistribution due to material removal in a plate, in: Thirty-second Japanese Congress. Mater. Res., Soc. Mat. Sci., 1989, pp. 134-141. [11] H.C. Hsu, An elasto-viscoplastic finite element model of orthogonal metal cutting for residual stress prediction, $\mathrm{PhD}$ Thesis, North Carolina State University, 1993.

[12] M.W. Joerms, Calculation of residual stresses in railroad rails and wheels from sawcut displacement, in: Resid. Str. Design, Process. Mater. Select., ASM Int., 1987, pp. 205-209.

[13] Z.C. Lin, B. Lee, Investigation of the residual stress of a machined workpiece considering tool flank wear, J. Mater. Process. Tech. 51 (1/4) (1995) 1-24.

[14] Z.C. Lin, Y.Y. Lin, C.R. Liu, Effect of thermal load and mechanical load on the residual stress of a machined workpiece, Int. J. Mech. Sci. 33 (4) (1991) 263-278. 
[15] Z.C. Lin, et al., The influence of the degree of constraint on the residual stress of the machined workpiece, Comp. Meth. Appl. Mech. Eng. 108 (1/2) (1993) $37-52$.

[16] F. Maseeh, M.A. Schmidt, M.G. Allen, S.D. Senturia, Calibrated measurements of elastic limit, modulus, and the residual stress of thin films using micromachined suspended structures, in: Int. SolidState Circ. Conf., IEEE, 1988, pp. 84-87.

[17] A. Mishra, An analysis of residual stresses due to the grinding process, PhD Thesis, IIT Delhi, India, 1976.

[18] A. Mishra, T. Prasad, Residual stresses due to a moving heat source, Int. J. Mech. Sci. 27 (1985) $571-$ 581.

[19] R. Natarajan, S. Jeelani, Residual stresses in machining using finite element method, Comput. Eng., Comput. Software Appl., ASME, 3 (1983) 79-80.

[20] F.G. Rammerstorfer, F.D. Fischer, A method for the experimental determination of residual stresses in axisymmetric composite cylinders, J. Eng. Mater. Technol., ASME 114 (1) (1992) 90-96.

[21] F.G. Rammerstorfer, F.D. Fischer, The computational verification of a new procedure for the experimental determination of residual stresses in compound rollers, in: H. Fujiwara, et al. (Eds.), Residual Stresses-III, Elsevier, Amsterdam, 1992, pp. 12411247.

[22] R.P. Ried, E.S. Kim, D.M. Hong, R.S. Muller, Residual stress compensation in clamped-clamped micromachined plates, Winter Ann. Meet., Anaheim, DSC 40, ASME (1992) 23-32.

[23] T. Sato, H. Kobayashi, Y. Arai, Finite element analysis of residual stresses of ceramics/metal joints (effect of cutting on redistribution of residual stresses), Trans. Jpn. Soc. Mech. Eng., Ser A 57 (540) (1991) 801-807.

[24] A.J. Shih, H.T.Y. Yang, Experimental and finite element predictions of residual stresses due to orthogonal metal cutting, Int. J. Num. Meth. Eng. 36 (9) (1993) $1487-1507$.

[25] T. Shirakashi, T. Obikawa, H. Sasahara, T. Wada, Analytical prediction of the characteristics within machined surface layer (1st Rep., The analysis of the residual stress distribution), J. Jpn. Soc. Precis. Eng. 59 (10) (1993) 1695-1700.

[26] T. Shirakashi, T. Obikawa, H. Sasahara, T. Wada, Effect of tool condition on residual stress distribution within machined sublayer, J. Jpn. Soc. Precis. Eng. 59 (12) (1993) 2003-2008.

[27] H.L. Stark, J. Bau, D.W. Kelly, Destructive procedure to determine the residual stresses in thick-walled cylindrical pressure vessels, J. Strain Anal. Eng. Des. 29 (1) (1994) 57-63.

[28] W.M. Szydlowski, W.N. Weins, S.K. Gumate, A. Dhir, Evaluation of residual stresses in axisymmetric bodies from post-grinding deformation by finite element method, in: Aerotech '92, Anaheim, SAE, 1992, pp. 1-9.

[29] C. Wiesner, Residual stresses after orthogonal machining of AISI 304: Numerical calculation of the thermal component and comparison with experiments, Metall. Trans. A 23 (3) (1992) 989-996.

[30] L. Zhang, M. Mahdi, Applied mechanics in grinding- IV: Mechanism of grinding induced phase transformation, Int. J. Mach. Tools Manuf. 35 (10) (1995) 1397-1409.

\section{A.6. Dynamic analysis and control of machine tools}

[1] Y. Altintas, D. Montgomery, E. Budak, Dynamic peripheral milling of flexible structures, in: B. Singh (Ed.), Comp. Model. Simul. Manuf. Proc., MD 20, ASME, 1990, pp. 25-35.

[2] Y. Altintas, D. Montgomery, E. Budak, Dynamic peripheral milling of flexible structures, J. Eng. Ind., ASME 114 (2) (1992) 137-145.

[3] N. Arai, et al., Study on low frequency vibratory drilling of SUS304 (Cutting temperature of drill point), Trans. Jpn. Soc. Mech. Eng., Ser C 56 (527) (1990) 1960-1964.

[4] S. Berczynski, P. Gutowski, Identification of parameters of machine tool dynamic models, Des.: Anal., Synth. Appl. PD 64, ASME (1994) 565-575.

[5] Z.M. Bzymek, G. Song, T.D. Howes, R.E. Garrett, Design of flexible grinding wheel with variable hub thickness, J. Eng. Ind., ASME 116 (2) (1994) 260-262. [6] E. Ceretti, G. Maccarini, F. Cotta-Ramusino, L. Milani, Redefining vibration stability by FEM analysis, Werkstatt. Betrieb 128 (5) (1995) 1-4.

[7] Y. Chen, Dynamic analysis and diagnostic monitoring for high speed spindle-bearing structures, PhD Thesis, The University of Wisconsin, Madison, 1986.

[8] Y.B. Chen, S.M. Wu, Dynamic analysis of rotating spindle-bearing system via FEM and DDS methodology, in: 14th NAMRC, SME, 1986, pp. 465-470.

[9] S.K. Choudhury, J. Mathew, Investigations of the effect of nonuniform insert pitch on vibration during face milling, Int. J. Mach. Tools Manuf. 35 (10) (1995) $1435-1444$.

[10] J.N. Dube, Comparison of computer and model techniques for dynamic analysis of milling machine structure, in: Second Nat. Machine Design Prod. Congress, METU, Ankara, 1986.

[11] J.N. Dube, Computer-aided design of machine-tool structure with model techniques, Comput. Struct. 28 (1988) 345-352.

[12] M.A. Elbestawi, R. Sagherian, Dynamic modeling for the prediction of surface errors in the milling of thin-walled sections, J. Mater. Process. Technol. 25 (2) (1991) 215-228. 
[13] J.A. Embry, S.W. Smith, B.L. Walcott, System identification for boring bar chatter control, Vibr. Contr. Mech. Syst., ASME DE 61 (1993) 199-207.

[14] F. Erfurt, W. Tietz, The application of modal-analysis in connection with the finite-element method to determine the dynamic behaviour of machine tools, in: D.J. DeMichele (Ed.), Fifth International Modal Anal. Conf., Union College, 1987, pp. 766-771.

[15] R. Finke, Berechnung des dynamischen Verhaltens von Werkzeugmaschinen, Diss, RWTH Aachen, Germany, 1977.

[16] G. Franceschini, et al., Dynamic properties characterization of a ball screw based tool unit family, in: Tenth International Modal Anal. Conf., SEM, 1992, pp. $1288-1294$.

[17] M. Glavonjic, V.R. Milacic, A practical procedure for conceptual design and testing of machine tool structure, Robotics Comput. Integr. Manuf. 4 (3/4) (1988) 317-333.

[18] Z. Han, J. Li, J. Qin, Identification method of the modal parameters of lathe spindle assembly, Struct. Dyn. Vib., London, PD 64, ASME (1994) 109-113.

[19] S. Haranath, N. Ganesan, B.V.A. Rao, Dynamic behaviour of saw blade with applied damping treatment, in: T. Kant (Ed.), Finite Elem. Comp. Mech., Pergamon, Oxford, 1985, pp. 771-780.

[20] S. Haranath, N. Ganesan, B.V.A. Rao, Dynamic analysis of machine tool structures with applied damping treatment, Int. J. Mach. Tools Manuf. 27 (1) (1987) $43-55$.

[21] S. Haranath, N. Ganesan, B.V.A. Rao, Dynamic analysis of machine tool column with damping layerfinite element approach, Int. J. Mach. Tools Manuf. 27 (1) (1987) 27-41.

[22] Q. He, et al., Finite element study of dynamic characteristics of main components of machine tools, Appl. Math. Mech. 2 (6) (1981) 743-755.

[23] E.E. Huang, D.K. Lieu, Reduction of precision spindle vibration by radial shear-layer damping, in: Fourteenth Biennial ASME Conference on Vib. Noise, Albuquerque, 1993, pp. 31-37.

[24] C. Ispas, C. Dogariu, C. Mohora, Research on machine tools bed dynamic behavior, Mech. Ind. Mater. 47 (4) (1994) 445-447.

[25] T.R. Kim, Dynamic analysis of tool-holder systems, $\mathrm{PhD}$ Thesis, The University of Wisconsin, Madison, 1986.

[26] H.Y. Lai, Computer aided milling machine modal analysis, in: Fourth International Modal Conf., Los Angeles, Union College, 1986, pp. 1140-1148.

[27] J.M. Lee, et al., Vibration and chatter analysis of an NC lathe, in: Proceeding of the Fourth International Modal Conf., Los Angeles, Union College, 1986, pp. 781-786.

[28] S.J. Lee, S.G. Kapoor, Cutting process dynamics simulation for machine tool structure design, J. Eng. Ind., ASME 108 (1986) 68-74.
[29] C.L. Liao, Y.S. Tarng, Dynamic response of a workpiece in turning with continuously varying speed, Comput. Struct. 45 (5/6) (1992) 901-909.

[30] C.L. Liao, J.S. Tsai, Dynamic response analysis in end milling using pre-twisted beam finite elements, J. Mater. Process. Technol. 40 (3/4) (1994) 407-432.

[31] C.L. Liao, J.S. Tsai, Dynamic response analysis in end milling using pretwisted beam finite element, J. Vib. Acoust., ASME, 117 (1) (1995) 1-10.

[32] H.R. Lii, et al., A dynamic mechanistic model of cutting forces in end milling, in: Proceedings of the Eighth National Conference CSME, Taipei, Taiwan, 1991, pp. 1001-1010.

[33] Y.H. Lin, M.W. Trethewey, Finite element analysis and experimental model verification for structures subjected to moving dynamic loads, in: Proceedings of the Tenth International Modal Anal. Conf., SEM, 1992, pp. 1057-1063.

[34] Y.H. Lin, et al., Dynamic modeling and analysis of a high speed precision drilling machine, J. Vib. Acoust., ASME, 112 (3) (1990) 355-365.

[35] Y.H. Lin, et al., Modeling of a precision drilling machine with a moving load finite element model and experimental modal data, in: Proceedings of the Eighth International Modal Anal. Conf., SEM, 1990, pp. 827832.

[36] K.J.J. Liu, Vibration control of cutting process in milling using dynamic absorber, PhD Thesis, University of Kentucky, 1993.

[37] K. Marchelek, S. Berczynski, A. Witek, Modification of machine tool dynamical properties using vibration absorbers, in: ASME Design Technology Conference, Montreal, DE 18-2, ASME (1989) 85-90.

[38] M. Matsuo, et al., A high-speed test of thermal effect for a machine-tool structure based on modal analysis, J. Jpn. Soc. Precis. Eng. 50 (1984) 1413-1418. [39] T. Moriwaki, et al., Development of modeling system for CAD/CAE of machine tool: application of thermal analysis for moving parts, J. Jpn. Soc. Precis. Eng. 60 (7) (1994) 959-963.

[40] N. Nicoletti, D. Fendeleur, L. Nilly, M. Renner, Using finite elements to model circular saw roll tensioning, Holz Roh. Werkst. 54 (2) (1996) 99-104.

[41] K. O'Shea, Enhanced vibration control of ultrasonic tooling using finite element analysis, in: 1991 ASME Design Tech. Conf., Miami, DE 37, ASME (1991) 259-265.

[42] K.E. Prasad, M.A. Rao, R.V. Dukkipati, M. Tummala, Dynamic analysis of radial drilling machine using FEM, in: Winter Ann. Meet., Anaheim, NCA 14, ASME (1992) 183-194.

[43] R.C. Radulescu, A general cutting process model for high-speed machining: dynamic and thermal considerations, PhD Thesis, University of Illinois, Urbana, 1993. 
[44] S. Ram, J.N. Dube, Analysis of a milling machine structure for ribbing of the cross-arm, Comput. Struct. 30 (1988) 1355-1358.

[45] S. Ramachandran, T. Nagarajan, N.S. Prasad, Finite element approach to the dynamics of a machining robot, Int. J. Comput. Appl. Technol. 6 (4) (1993) 240-244.

[46] S.S. Rao, R.V. Grandhi, Optimum design of radial drilling machine structure to satisfy static rigidity and natural frequency requirements, J. Mech., Transm., Aut. Des., ASME 105 (1983) 236-241.

[47] C.P. Reddy, S.S. Rao, Automated optimum design of machine tool structures for static rigidity, natural frequencies and regenerative chatter stability, J. Eng. Ind., ASME 100 (1978) 137-146.

[48] V.R. Reddy, A.M. Sharan, Design of machine tool spindles based on transient analysis, J. Mech., Transm., Aut. Des., ASME 107 (1985) 346-352.

[49] V.R. Reddy, A.M. Sharan, The finite element modelled design of lathe spindles: the static and dynamic analyses, J. Vib. Acoust. Stress., ASME 109 (1987) 407-415.

[50] J. Rotberg, E. Lenz, S. Braun, Vibration-based drill wear monitoring, Manuf. Rev. 3 (1) (1990) 60-65. [51] T.D. Sachdeva, Finite element analysis of elastic contact problem and its application for the study of the effect of joint flexibility of the free vibration characteristics, PhD Thesis, IIT Delhi, India, 1979.

[52] T.D. Sachdeva, C.V. Ramakrishnan, The effect of interface friction on the inplane flexibilities of machine tool joints, Int. J. Mech. Sci. 23 (1981) 149-159.

[53] K.H.W. Seah, Y.S. Wong, L.C. Lee, Design of tool holders for ultrasonic machining using FEM, J. Mater. Process. Technol. 37 (1/4) (1993) 801-816.

[54] A. Shabana, B. Thomas, Chatter vibration of flexible multibody machine tool mechanisms, Mech. Mach. Theory 22 (4) (1987) 359-370.

[55] A.M. Sharan, S. Sankar, T.S. Sankar, Dynamic behavior of lathe spindles with elastic support including damping by finite element analysis, 51st Shock Vibrat. Bull. (1981) 83-96.

[56] A.M. Sharan, S. Sankar, T.S. Sankar, Dynamic analysis and optimal selection of parameters of a finite element modeled lathe spindle under random cutting forces, J. Vib. Acoust. Stress., ASME 105 (1983) 467475.

[57] A.M. Sharan, S. Sankar, T.S. Sankar, The optimal design of lathe spindles under experimentally measured random cutting force excitations, Finite Elem. Anal. Des. 3 (1987) 175-182.

[58] T. Shi, et al., Dynamic modeling of face mill arbor and turning tool support assembly for tool condition monitoring, in: 15th NAMRC, Lehigh University, Bethlehem, PA, vol. 2, 1987, pp. 469-476.

[59] M. Subbiah, A.M. Sharan, J. Jain, Study of the dynamic condensation techniques for the machine tools and robotic manipulators, Mech. Mach. Theory 23 (1) (1988) 63-69.

[60] O. Tekinalp, Dynamic modeling of drill bit vibrations, PhD Thesis, The University of Michigan, 1988. [61] O. Tekinalp, A.G. Ulsoy, Effects of geometric and process parameters on drill transverse vibrations, in: Winter Ann. Meet., Chicago, PED 33, ASME (1988) $33-40$.

[62] O. Tekinalp, A.G. Ulsoy, Modeling and finite element analysis of drill bit vibrations, in: 1989 ASME Design Tech. Conf., Montreal, DE 18-2, ASME (1989) 61-68.

[63] O. Tekinalp, A.G. Ulsoy, Effects of geometric and process parameters on drill transverse vibrations, J. Eng. Industry, ASME 112 (2) (1990) 189-194.

[64] S.G. Tewani, Active vibration control of a boring bar using active dynamic absorber, $\mathrm{PhD}$ Thesis, University of Kentucky, 1992.

[65] H.K. Tonshoff, J. Jendryschik, Dynamical behavior of disklike rotating tools, Comput. Struct. $21(1 / 2)$ (1985) 203-211.

[66] P. Vanhonacker, Sensitivity analysis of mechanical structures, based on experimentally determined modal parameters, in: Proceedings of the First International Modal Anal. Conf., Orlando, FL, Union College, 1982, pp. 534-541.

[67] J. Vogel, et al., On tool post vibration monitoring for tool condition identification, in: 14th NAMRC, SME, 1986, pp. 281-285.

[68] W.R. Wang, C.N. Chang, Dynamic analysis and design of a machine tool spindle-bearing system, J. Vib. Acoust., ASME, 116 (3) (1994) 280-285.

[69] M. Weck, H. Helpenstein, Richtlinien fur die Berechnung und Beurteilung dynamisch belasteter Werkzeugmaschinenbauteile, VDW-Ber. 0132, VDW, Frankfurt a M, 1981.

[70] M. Weck, W. Miessen, W. Mueller, E.K. Proessler, Determination of the dynamic behavior of a crankshaft milling unit, Werkstattstechnik 67 (3) (1977) 155-160. [71] Z. Weizhong, The dynamic optimum design for the wheel head of a cylindrical grinding machine, in: Proceedings of the Second International Modal Anal. Conf., Orlando, Union College, 1984, pp. 254-258.

[72] Z. Wen, et al., Structural parameter identification of machine tool spindle supports by complex condensation method, in: Proceedings of the Sixth International Modal Anal. Conf., Kissimmee, vol. 2, SEM, 1988, pp. 1283-1287.

[73] B.H. Wilson, J. Gao, Applications of continuumbased models of machine tool spindle drives, in: Proceedings of the American Contr. Conference, Baltimore, 1994, pp. 3318-3322.

[74] W.Z. Wu, Modal testing and analysis in continuous band systems, in: Proceedings of the Third International Modal Anal. Conf., Orlando, Union College, 1985, pp. 908-914. 
[75] K.Z.Y. Yen, W.C. Hsueh, Suppression of chatter vibration in inner-diameter cutting, JSME Int. J., Ser C 39 (1) (1996) 25-33.

[76] M. Yoshimura, Study on optimum design of machine structures with respect to dynamic characteristics, Bull. JSME 20 (145) (1977) 811-818.

[77] M. Yoshimura, T. Hamada, K. Yura, K. Hitomi, Design optimization of machine-tool structures with respect to dynamic characteristics, J. Mech., Transm., Aut. Design, ASME 105 (1983) 88-96.

[78] D. Yu, et al., Dynamic analysis of machine tool column via modal test and FEM, in: Proceedings of the Eighth International Modal Anal. Conf., SEM, 1990, pp. $1386-1389$.

[79] J.X. Yuan, Identification of the machine tool structural parameters by dynamic data system (DDS) and finite element method, PhD Thesis, University of Wisconsin, Madison, 1983.

[80] J.X. Yuan, X.M. Wu, Identification of the joint structural parameters of machine tool by DDS and FEM, J. Eng. Ind., ASME 107 (1985) 64-69.

[81] J.X. Yuan, X.J. Tang, S.M. Wu, An application of DDS combined with FEM using condensation technique for machine tool design, in: ASME Winter Ann. Meet., Boston, (1983) 89-95.

\section{A.7. Tool wear and failure}

[1] X. Ai, C. Xia, Study on the criterion for ceramic tool fracture in intermittent steel turning, Chin. J. Mech. Eng. 3 (1) (1990) 1-8.

[2] N. Arai, et al., Study on diffusion wear on the rake face of boride-cermet tools, Trans. Jpn. Soc. Mech. Eng., Ser C 59 (559) (1993) 915-920.

[3] H. Berns, Crack initiation and growth in tool steels, in: Fatigue 90, Honolulu, Hawaii (1990) 161-166.

[4] G.T. Camacho, et al., Modelling of high-speed machining and ballistic penetration, in: D.R.J. Owen (Ed.), Proceedings of the Fourth International Conference on Comp. Plast., vol. 2, Pineridge Press, 1995, pp. 1835-1863.

[5] J.F.L. Chan, P.M. Braiden, Effect of reverse shear on the failure of metal cutting tools, J. Mater. Process. Technol. 28 (1/2) (1991) 75-82.

[6] T.H.C. Childs, K. Maekawa, Computer-aided simulation and experimental studies of chip flow and tool wear in the turning of low alloy steels by cemented carbide tools, Wear 139 (2) (1990) 235-250.

[7] S. Hanasaki, M. Nomura, Analysis of carbon-fiberreinforced plastic cutting mechanism by finite element method (fracture behavior of fiber at entry of cutting), Trans. Jpn. Soc. Mech. Eng., Ser C 61 (583) (1995) $1163-1168$.

[8] G.D. Hiatt, A fracture mechanics technique for predicting the ductile regime in single point diamond turning of brittle materials, PhD Thesis, North Carolina State University, 1992.

[9] T. Hongo, I. Tanabe, M. Kano, C. Fujii, J. Miyata, Development of ceramics resin concrete for precision machine tool structure (continuation of tool life), Trans. Jpn. Soc. Mech. Eng., Ser C 62 (593) (1996) 333-337.

[10] K. Isogimi, M. Uchida, Observations of early-stage damage of a sintered carbide tool, Trans. Jpn. Soc. Mech. Eng., Ser C 56 (527) (1990) 1969-1973.

[11] Y. Kakino, et al., A study on the generation of thermal crack of cutting tool, J. Jpn. Soc. Precis. Eng. 51 (1985) 1705-1710.

[12] K. Kanazawa, M. Fukushima, K. Asano, T. Shimada, Analytical prediction of failure in cemented carbide endmill, J. Jpn. Soc. Precis. Eng. 60 (6) (1994) 822-826.

[13] R. Lapovok, A damage mechanics approach to fatigue fracture of tools in metal working processes, in: D.R.J. Owen (Ed.), Proceedings of the Fourth International Conference Comp. Plast., vol. 2, Pineridge Press, 1995, pp. 1119-1130.

[14] L.C. Lee, K.Y. Lam, X.D. Liu, Characterisation of tool wear and failure, J. Mater. Process. Technol. 40 (1/2) (1994) 143-153.

[15] Z.C. Lin, W.C. Pan, A thermoelastic-plastic deformation model for orthogonal cutting with tool flank wear-Part II: Machining application, Int. J. Mech. Sci. 35 (10) (1993) 841-850.

[16] Z.C. Lin, W.C. Pan, A thermo-elastic-plastic model with special elements in a cutting process with tool flank wear, Int. J. Mach. Tools Manuf. 34 (6) (1994) $757-770$.

[17] Z.C. Lin, F.S. Chang, Y.T. Lin, The effect of tool flank wear on the temperature distribution of a machined workpiece, J. Chin. Inst. Eng. 10 (4) (1987) $353-362$.

[18] Z.C. Lin, W.C. Pan, S.P. Lo, Study of orthogonal cutting with tool flank wear and sticking behavior on the chip-tool interface, J. Mater. Process. Technol. 52 (2/4) (1995) 524-538.

[19] K. Maekawa, H. Ohhata, Simulation analysis of three-dimensional continuous chip formation processes (3rd Rep-Effects of tool geometry on chip flow and wear), J. Jpn. Soc. Precis. Eng. 62 (4) (1996) 535-539. [20] K. Maekawa, T. Shirakashi, T. Obikawa, Recent progress of computer aided simulation of chip flow and tool damage in metal machining, Proc. Inst. Mech. Eng., Part B 210 (3) (1996) 233-242.

[21] M. Nakamura, et al., A study on cracks near machined surface of brittle material-numerical analysis with finite element method, J. Jpn. Soc. Precis. Eng. 53 (1987) 117-123.

[22] M. Nishi, T. Sugita, Y. Funada, Strength reliability evaluation of ceramics (5th Rep-A proposal of strength reliability evaluation method for ceramics with 
machining damage), J. Jpn. Soc. Powder Powder Metall. 41 (11) (1994) 1419-1425.

[23] D.A. O'Neil, S.F. Wayne, Numerical simulation of fracture in coated brittle materials subjected to tribocontact, J. Eng. Mater. Technol., ASME 116 (4) (1994) $471-478$.

[24] J. Rotberg, E. Lenz, S. Braun, Vibration-based drill wear monitoring, Manuf. Rev. 3 (1) (1990) 60-65. [25] A.B. Sadat, W.S. Chan, B.P. Wang, Delamination of graphite/epoxy laminate during drilling operation, Compos. Mater. Technol. PD 32, ASME (1990) 85-88. [26] A.B. Sadat, W.S. Chan, B.P. Wang, Delamination of graphite and epoxy laminate during drilling operation, J. Energy Res. Technol., ASME 114 (2) (1992) $139-141$.

[27] W.S. Sampath, Y.M. Lee, M.C. Shaw, Tool fracture probability under steady state cutting conditions, J. Eng. Ind., ASME 106 (1984) 161-167.

[28] K. Sekiya, R. Kitagawa, Correspondence of the stress analysis of chamfered cutting tools by the finite element method with the tool failure in interrupted cutting, Mem. Fac. Eng., Yamaguchi Univ., 41 (2) (1991) 35-42.

[29] V.G. Sharrock, J.C. Coetzee, Fatigue cracks in grinding mills, Forensic Eng. 3 (1) (1991) 55-62.

[30] T. Sugita, et al., Fracture mechanics study on microcutting of ceramics - mechanism of material removal process with residual crack, J. Jpn. Soc. Precis. Eng. 51 (1985) 1940-1945.

[31] J. Tlusty, Z. Masood, Chipping and breakage of carbide tools, J. Eng. Ind., ASME 100 (4) (1978) 403412.

[32] H.K. Toenshoff, S. Bartsch, Wear of aluminum oxide tools in steel cutting, Adv. Manuf. Process. 2 (3/4) (1987) 167-301.

[33] H.K. Toenshoff, B. Denkena, Wear of ceramic tools in milling, Lubricat. Eng. 47 (9) (1991) 772-778.

[34] K. Ueda, et al., Fracture mechanics analysis of the brittle failure of cutting tools, J. Jpn. Soc. Precis. Eng. 48 (1982) 1311-1316.

[35] K. Ueda, T. Sugita, H. Hiraga, A J-integral approach to material removal mechanisms in microcutting of ceramics, Ann. CIRP 40 (1) (1991) 61-64.

[36] K. Ueda, et al., Analysis of lamellar slip mechanism in microcutting of amorphous metal, J. Jpn. Soc. Precis. Eng. 58 (5) (1992) 847-852.

[37] E. Usui, et al., Study on analytical prediction of cutting tool life - shape of flank wear surface and its stress state, J. Jpn. Soc. Precis. Eng. 48 (1982) $1231-$ 1237.

[38] E. Usui, et al., A critical examination of application of linear fracture mechanics to impact brittle failure of carbide cutting tool, J. Jpn. Soc. Precis. Eng. 52 (1986) 1354-1361.

[39] S. Vichev, V. Kirov, D. Hristov, Strength calculation of cutting tools, Int. J. Machine Tools Manuf. 34 (1) (1994) 13-18.
[40] Z.Y. Wang, C. Sahay, K.P. Rajukar, Tool temperatures and crack development in milling cutters, Int. J. Mach. Tools Manuf. 36 (1) (1996) 129-140.

[41] D.F. Watt, P. Nadin, S.B. Biner, Fracture toughness of very hard tool steels, in: W.R. Tyson, et al. (Eds.), Int. Symp. Fract. Mech., Pergamon, Oxford, 1988, pp. $169-176$.

[42] H. Wu, J.E. Mayer, An analysis of thermal cracking of carbide tools in intermittent cutting, J. Eng. Ind., ASME 101 (2) (1979) 159-164.

[43] Y. Yang, Y. Mukoyama, H. Kato, T. Hanaoka, Analysis of crack generative region in crater machined by impulsive electrical discharge, J. Jpn. Soc. Precis. Eng. 60 (3) (1994) 388-392.

[44] R.K. Yee, Shear localization and ductile fracture in metal cutting, PhD Thesis, University of California, Berkeley, 1990.

[45] J.B. Young, M.A. Sheikh, Crack growth characteristics of integrally machined stringer-skin panels, Aeronaut. J. 99 (982) (1995) 63-68.

[46] C.L. Zone, C.P. Wen, P.L. Ship, Study of orthogonal cutting with tool flank wear and sticking behavior on the chip-tool interface, J. Mater. Process. Technol. $52(2 / 4)(1995) 524-538$.

\section{A.8. Chip formation mechanism}

[1] A.E. Bayoumi, V.H. Zbib, Characterization of chip formation and shear banding in orthogonal machining using finite element analysis, in: Symp. Mater. Instabil., AMD 15, ASME (1994).

[2] E. Ceretti, P. Fallbohmer, W.T. Wu, T. Altan, Application of 2D FEM to chip formation in orthogonal cutting, J. Mater. Process. Technol. 59 (1/2) (1996), pp. 169-180.

[3] W.T. Chien, A numerical and experimental investigation of the sticking and sliding contact regions at the chip-tool interface in machining of aluminum, $\mathrm{PhD}$ Thesis, North Carolina State University, 1992.

[4] T.H.C. Childs, K. Maekawa, Computer-aided simulation and experimental studies of chip flow and tool wear in the turning of low alloy steels by cemented carbide tools, Wear 139 (2) (1990) 235-250.

[5] J. Hashemi, Finite element simulation of segmented chip formation in high-speed machining, $\mathrm{PhD}$ Thesis, Drexel University, 1988.

[6] J. Hashemi, A. Tseng, C. Chou, Finite element modeling of segmental chip formation in high speed orthogonal cutting, in: 50th Anniv. Spring Conf. Exper. Mech., Dearborn, MI, SEM, 1993, pp. 248-256.

[7] J. Hashemi, A. Tseng, C. Chou, Finite element modeling of segmental chip formation in high speed orthogonal cutting, J. Mater. Eng. Perform. 3 (6) (1994) $712-721$. 
[8] M. Hashimura, K. Ueda, D. Dornfeld, K. Manabe, Analysis of three-dimensional burr formation of oblique cutting, Ann. CIRP 44 (1) (1995) 27-30.

[9] J.F. Li, N. Nishio, A. Kawasaki, R. Watanabe, Development of diamond tools for superprecision machining with compositionally graded layers from silicon carbide shank of diamond chip, J. Jpn. Soc. Powder Powder Metall. 41 (6) (1994) 653-657.

[10] Z.C. Lin, W.C. Pan, S.P. Lo, Study of orthogonal cutting with tool flank wear and sticking behavior on the chip-tool interface, J. Mater. Process. Technol. 52 (2/4) (1995) 524-538.

[11] K. Maekawa, M. Maeda, Simulation analysis of 3D continuous chip formation processes, J. Jpn. Soc. Precis. Eng. 59 (11) (1993) 1827-1832.

[12] K. Maekawa, H. Ohhata, Simulation analysis of three-dimensional continuous chip formation processes (3rd Rep-Effects of tool geometry on chip flow and wear), J. Jpn. Soc. Precis. Eng. 62 (4) (1996) 535-539. [13] K. Maekawa, H. Ohhata, Simulation analysis of three-dimensional continuous chip formation processes (4th Rep, Effects of workpiece and tool materials on 3D cutting), J. Jpn. Soc. Precis. Eng. 62 (5) (1996) 661-665.

[14] K. Maekawa, T. Shirakashi, T. Obikawa, Recent progress of computer aided simulation of chip flow and tool damage in metal machining, Proc. Inst. Mech. Eng., Part B 210 (3) (1996) 233-242.

[15] K. Manabe, K. Ueda, S. Tomiyama, Rigid-plastic FEM analysis of three-dimensional cutting mechanism. Chip formation mechanism in oblique cutting, J. Jpn. Soc. Precis. Eng. 59 (10) (1993) 1701-1706.

[16] T.D. Marusich, M. Ortiz, Simulation of chip formation in high-speed machining, Joint ASME Appl. Mech. Mater. Meet., AMD 208, ASME (1995) $127-$ 139.

[17] G. Meir, et al., Finite-element simulation of segmented chipping in high-speed machining, in: Adv. Machining Tech. II, Soc. Manuf. Eng., Dearborn, 1988, pp. $405-420$.

[18] T. Obikawa, E. Usui, FEM analysis on serrated chip formation of titanium alloy, J. Jpn. Soc. Precis. Eng. 58 (6) (1992) 1072-1078.

[19] T. Obikawa, E. Usui, FEM analysis on serrated chip formation of titanium alloy, (2nd Rep, Chip formation mechanism and cutting properties of titanium alloy), J. Jpn. Soc. Precis. Eng. 59 (6) (1993) 933-938. [20] T. Obikawa, H. Sasahara, E. Usui, Finite element approach to chip breaker, J. Jpn. Soc. Precis. Eng. 58 (12) (1992) 2051-2056.

[21] T. Obikawa, J. Shinozuka, T. Shirakashi, Analytical prediction of cutting performances of grooved rake face tools, J. Jpn. Soc. Precis. Eng. 61 (9) (1995) $1295-1299$.

[22] G.S. Sekhon, J.L. Chenot, Numerical simulation of continuous chip formation during non-steady orthogonal cutting, Eng. Comput. 10 (1) (1993) 31-48.
[23] T. Shirakashi, E. Usui, Analytical prediction of time dependency of chipping occurrence in interrupted turning operation, in: Proceedings of the First Internatioal Metal Cutting Conference, China Acad., 1985, pp. 243-261.

[24] J.S. Strenkowski, K.J. Moon, Finite element prediction of chip geometry and tool/workpiece temperature distributions in orthogonal metal cutting, J. Eng. Industry, ASME 112 (4) (1990) 313-318.

[25] J. Tlusty, Z. Masood, Chipping and breakage of carbide tools, J. Eng. Industry, ASME 100 (4) (1978) 403-412.

[26] K. Ueda, K. Manabe, Analysis of chip formation mechanism of beta-brass single crystals by rigid-plastic FEM, J. Jpn. Inst. Light Met. 56 (3) (1992) 327-332. [27] K. Ueda, K. Manabe, Chip formation mechanism in microcutting of an amorphous metal, Ann. CIRP 41 (1) (1992) 129-132.

[28] K. Ueda, K. Manabe, Elastic-plastic FEM simulation of chip formation mechanisms based on Gurson's yield function, Trans. Jpn. Soc. Mech. Eng., Ser C 59 (560) (1993) 1274-1279.

[29] K. Ueda, K. Manabe, Rigid-plastic FEM analysis of three-dimensional deformation field in chip formation process, Ann. CIRP 42 (1) (1993) 35-38.

[30] E. Usui, et al., Analytical prediction of cutting edge chipping in interrupted turning operation-distributions of impact stress and fracture probability, J. Jpn. Soc. Precis. Eng. 46 (1980) 983-989.

[31] E. Usui, et al., Analytical prediction of cutting edge chipping in interrupted turning operation (7th RepVariation of probability of edge failure), J. Jpn. Soc. Precis. Eng. 50 (1984) 866-874.

[32] S.F. Wayne, et al., Aspects of advanced cutting tool and chip-flow modeling, in: Proceedings of the Thirteenth International Plansee Seminar, Reutte, Austria, 1993, pp. 603-615.

[33] J.Q. Xie, A.E. Bayoumi, H.M. Zbib, Characterization of chip formation and shear banding in orthogonal machining using finite element analysis, in: 1994 Int. Mech. Eng. Cong. Expo. AMD 183, ASME (1994) 285-301.

[34] J.Q. Xie, A.E. Bayoumi, H.M. Zbib, Analytical and experimental study of shear localization in chip formation in orthogonal machining, J. Mater. Eng. Perform. 4 (1) (1995) 32-39.

[35] Q. Xie, An analytical study and finite element modeling of chip formation in metal machining process, PhD Thesis, Washington State University, 1994.

[36] J.A. Yang, A predictive model of chip breaking for groove-type tools in orthogonal machining of AISI 1020 steel, PhD Thesis, North Carolina State University, 1992.

[37] B. Zhang, A. Bagchi, Finite element simulation of chip formation and comparison with machining experiment, in: Winter Ann. Meet., Anaheim, MD 39, ASME (1992) 61-74. 
[38] B. Zhang, A. Bagchi, Finite element simulation of chip formation and comparison with machining experiment, J. Eng. Ind., ASME 116 (3) (1994) 289-297.

[39] B. Zhang, A. Bagchi, A study of chip separation and its approximation in finite element simulation of continuous chip formation, in: Mater. Issues Machining II, Chicago, AIME, 1994, pp. 157-174.

[40] C.L. Zone, C.P. Wen, P.L. Ship, Study of orthogonal cutting with tool flank wear and sticking behavior on the chip-tool interface, J. Mater. Process. Technol. $52(2 / 4)(1995) 524-538$.

\section{A.9. Optimization and other topics}

[1] G. Bianchi, F. Paolucci, P. Van den Braembussche, $\mathrm{H}$. Van Brussel, Towards virtual engineering in machine tool design, Ann. CIRP 45 (1996) 381-384.

[2] R. Butt, Optimum design with finite elements: design of electrochemical machining, J. Comput. Appl. Math. 47 (2) (1993) 151-165.

[3] U. Chandra, Validation of finite-element codes for prediction of machining distortions in forgings, Commun. Num. Meth. Eng. 9 (6) (1993) 463-473.

[4] K.H. Fuh, Computer aided design and manufacturing for multifacet drills, PhD Thesis, The University of Wisconsin, Madison, 1987.

[5] Z. Huang, S. Hinduja, Shape optimization of a foundation for a large machine tool, Int. J. Mach. Tool Dev. Res. 26 (2) (1986) 85-97.

[6] N.K. Jha, Computer aided multi-objective optimal design and finite element analysis of cutting tool, in: Proc. Manuf. Int. '90, Part 4, Atlanta, ASME (1990) $59-70$.

[7] N.K. Jha, H.H. Cheung, Computer aided optimal design and finite element analysis of plan milling cutter, in: 1989 ASME Int. Comp. Eng. Conf. Exhib., Anaheim, ASME (1989) 511-521.

[8] N.K. Jha, K. Hornik, Integrated computer aided optimal design and finite element analysis of a plain milling cutter, Appl. Math. Model. 19 (6) (1995) 343353.

[9] S. Jinmin, C. Hongyi, The development and connection of some optimal methods with the view of machine tool structure optimization practice, in: G. Yagawa, S.N. Atluri (Eds.), Comp. Mech. '86, Springer, Berlin, 1986, pp. X-121.

[10] J. Kratky, J. Sima, Calculation of column of type W $180 \mathrm{NC}$ horizontal boring and milling machine by finite element method, Skoda Rev (4) (1986) 40-44.

[11] S.J. Lee, S.G. Kapoor, Integrated process and structural optimization for face milling systems, in: R.P. Shaw (Ed.), Innov. Num. Meth. Eng., Springer, Berlin, 1986, pp. 513-518.

[12] S.J. Lee, S.G. Kapoor, On the automatic selection of reanalysis techniques in machine tool structural element optimization, Eng. Optim. 10 (1986) 163-181.
[13] C.H.H. Lo, Real-time error compensation on machine tool through optimal thermal error modeling, PhD Thesis, The University of Michigan, 1994.

[14] R.D. Lowrey, ANSYS/CIMPLEX modeling and analysis of machined parts, in: 1987 International ANSYS Conference Exh., Newport Beach, SAS, 1987.

[15] T. Moriwaki, et al., Development of modeling system for $\mathrm{CAD} / \mathrm{CAE}$ of machine tool: application of thermal analysis for moving parts, J. Jpn. Soc. Precis. Eng. 60 (7) (1994) 959-963.

[16] R. Murthy, et al., Optimisation of functional properties of machine tool structures - a finite element analysis, in: Proceedings of the Twentieth International MTDR Conference, 1979.

[17] P. Nielsen, H. Siemers, B. Helm, Technical and economic optimizing of a lathe bed, Konstr. Giessen. 19 (2) (1994) 36-37.

[18] P.C. Pong, R.R. Barton, P.H. Cohen, Optimum fixture design, in: Proceedings of the Second Ind. Eng. Res. Conference, Los Angeles, IIE, 1993, pp. 6-10.

[19] B. Prasad, R.T. Haftka, M.S. Bao, Optimum design of an abrasive disk, J. Mech. Design, ASME 103 (4) (1981) 818-822.

[20] K. Rall, C.U. Bauer, Finite element method to optimize a tool-machine stand, Konstr. Giessen. 15 (1) (1990) 14-18.

[21] S.S. Rao, R.V. Grandhi, Optimum design of radial drilling machine structure to satisfy static rigidity and natural frequency requirements, J. Mech., Transm., Aut. Design, ASME 105 (1983) 236-241.

[22] C.P. Reddy, S.S. Rao, Automated optimum design of machine tool structures for static rigidity, natural frequencies and regenerative chatter stability, J. Eng. Ind., ASME 100 (1978) 137-146.

[23] S.V.M. Selvam, C. Sujatha, Twist drill deformation and optimum drill geometry, Comput. Struct. 57 (5) (1995) 903-914.

[24] A.M. Sharan, S. Sankar, T.S. Sankar, The optimal design of lathe spindles under experimentally measured random cutting force excitations, Finite Elem. Anal. Des. 3 (1987) 175-182.

[25] P. Steinke, Optimale Auslegung von Bauteilen, Konstruktion 37 (1985) 373-380.

[26] Y. Tani, Y. Hatamura, T. Nagao, Development of small three-component dynamometer for cutting force measurement, Bull. JSME 26 (214) (1983) 650-658.

[27] Y. Wang, Computer graphics presentation of drilling operations, PhD Thesis, The University of Michigan, 1990.

[28] M. Weck, F. Fortsch, Shape optimization of fillets of machine tool components, in: Proceedings of the Twelfth IFIP Conference on Syst. Model. Optim., Budapest, 1985.

[29] M. Weck, G. Kolsch, Optimization of machine tools, a mixed-discrete-continuous problem, in: H. Eschenauer (Ed.), Discretiz. Meth. Str. Optim., Springer, Berlin, 1989, pp. 351-359. 
[30] M. Weck, W. Sprangers, Shape optimization in machine tool design, in: Proceedings of the International Conference on Eng. Optim. Design Proc., Karlsruhe, 1991, pp. 71-78.

[31] Z. Weizhong, The dynamic optimum design for the wheel head of a cylindrical grinding machine, in: Proceedings of the Second International Modal Anal. Conf., Orlando, Union College, 1984, pp. 254-258.

[32] H. Werning, Raising design rigidity of machine tool parts for optimized cast iron structures, Ing. Werkst. (4) (1992) 52-58.

[33] M. Yeong, et al., Techniques to reduce lead time in fixture design, in: Proc. Manuf. Int. MI 92, ASME (1992) 445-458.
[34] M. Yoshimura, Study on optimum design of machine structures with respect to dynamic characteristics, Bull. JSME 20 (145) (1977) 811-818.

[35] M. Yoshimura, T. Hamada, K. Yura, K. Hitomi, Design optimization of machine-tool structures with respect to dynamic characteristics, J. Mech., Transm., Autom. Design, ASME 105 (1983) $88-96$.

[36] M. Yoshimura, T. Hamada, K. Yura, K. Hitomi, Design optimization of machine-tool structures considering manufacturing cost, accuracy, and productivity, J. Mechan., Transm., Autom. Des., ASME 106 (1984) 531-537. 